\title{
Use of water isotopes and chemistry to infer the type and degree of exchange between groundwater and lakes in an esker complex of northeastern Ontario, Canada
}

\author{
Maxime P. Boreux ${ }^{1}$, Scott F. Lamoureux ${ }^{1}$, and Brian F. Cumming ${ }^{2,3}$ \\ ${ }^{1}$ Department of Geography and Planning, Queen's University, Kingston, K7L3N6, Canada \\ ${ }^{2}$ Department of Biology, Queen's University, Kingston, K7L3J9, Canada \\ ${ }^{3}$ School of Environmental Studies, Queen's University, Kingston, K7L3J9, Canada
}

Correspondence: Maxime P. Boreux (m.boreux@queensu.ca)

Received: 27 July 2017 - Discussion started: 24 August 2017

Revised: 12 July 2019 - Accepted: 9 August 2019 - Published: 13 December 2021

\begin{abstract}
While interactions between groundwater and lakewater influence water chemistry, water balance, aquatic organisms, biochemical cycles and contamination levels, they remain a poorly studied component of lake hydrology. Identifying the controls of groundwater and lake-water interactions at the landscape level and classifying lakes into categories based on their degree of interaction with the groundwater can provide insights into a lake's sensitivity and vulnerability to environmental stressors. Such information can also provide baseline conditions for comparison to future changes that are important for water management and conservation. To this end, water chemistry and water isotopic composition were investigated in a set of 50 boreal lakes located at different elevations in an esker system near Timmins, Ontario. Analyses focused on stable isotopic ratios of hydrogen and oxygen and specific conductance as indicators of the position of a lake with respect to the influence of groundwater. Both isotopic composition and specific conductance distinguished higher-elevation groundwater-recharge lakes from lower-elevation groundwater-discharge lakes. Groundwaterrecharge lakes were high-elevation lakes characterized by enriched isotopic values and low values of specific conductance. In contrast, groundwater-discharge lakes were isotopically depleted and had higher values of specific conductance and occurred at lower elevations. An intermediate group of lakes was also defined (termed seepage lakes) and had intermediate isotopic and water-chemistry characteristics compared to recharge and discharge lakes. Differences in water geochemistry between field campaigns revealed that upland
\end{abstract}

groundwater-recharge lakes showed evidence of evaporative drawdown, indicating sensitivity to short-term changes in climate, whereas the lower-elevation groundwater-discharge lakes showed little variation between seasonal samples and consequently would likely be affected only by hydroclimatological changes of greater duration and magnitude.

\section{Introduction}

Nearly all surface waters, including lakes, interact with groundwater to some extent (Winter et al., 1998; Winter, 1999; Cohen et al., 2016). The degree to which lakes interact with groundwater strongly influences lake-water chemistry and water balance as well as aquatic biota and biochemical cycles (Lewandowski et al., 2015; Rosenberry et al., 2015). The degree of hydrological connectivity will influence the sensitivity of lakes to environmental stressors such as climate change and other anthropogenic disturbances. Future climate change will likely affect lakes differently depending on groundwater-lake interactions, further increasing our need to better understand the relations between lake hydrology and lake-water geochemistry. Moreover, understanding the climatic controls on water balance is essential for informed ecosystem management and conservation practices (Okkonen and Kløve, 2011).

Interactions between groundwater and lakes are an often poorly studied component of lake hydrology. However, recent advances in isotopic techniques and modelling ap- 
proaches have given researchers the opportunity to better understand hydrological processes in lakes at a local to regional scale (Fleckenstein et al., 2010; Rosenberry et al., 2015). This has included studies using groundwater modelling (e.g. Winter, 1976; Smerdon et al., 2007; Okkonen and Kløve, 2011; Ala-aho et al., 2015a, b) as well as empirical studies at a range of different spatial and temporal scales. Studies at the regional scale (e.g. Gorham et al., 1983; Webster et al., 2000) emphasize differences in climate and surface geology as being the important drivers of changes in lake-water chemistry. By contrast, empirical studies performed at a local to regional scale (e.g. Webster et al., 1996; Quinlan et al., 2003; Martin and Soranno, 2006; Ala-aho et al., 2013; Thorslund et al., 2018) indicate the importance of landscape position and also lake morphology in understanding lake-groundwater interactions. At the scale of an individual lake, a number of studies have shown that interactions between groundwater and lakes can vary temporally according to changes in seasonality and longer-term changes in hydroclimatic conditions (e.g. Kenoyer and Anderson, 1989; LaBaugh et al., 1997; Sebestyen and Schneider, 2001; Schuster et al., 2003; Smerdon et al., 2005; Arnoux et al., 2017b).

The vast majority of past empirical studies have relied on studying aspects of water chemistry (e.g. dissolved ions) as an indicator of hydrological connectivity between lakes because such approaches can reveal signals of important processes such as mineral weathering and dissolution (Bertrand et al., 2014). Chemical tracers are often referred to as nonconservative tracers because their composition changes as they react with catchment materials (Kendall and McDonnell, 1998). By contrast, other studies rely on the isotopic composition of water as a hydrological tracer (e.g. Turner et al., 2010; Isokangas et al., 2015). These are labelled as conservative tracers because they are relatively conservative in reactions with catchment materials and retain their distinctive values until they mix with other water sources or they evaporate (Kendall and Caldwell, 1998). In addition to being a good indicator of source water, stable isotopes of water constitute an efficient and cost-effective means to quantify lake evaporation and water balance of water bodies using the Craig-Gordon model (Craig and Gordon, 1965), given that the isotopic composition of lake water and precipitation as well as air temperature and relative humidity are known or can be estimated (Gibson and Edwards, 2002). The CraigGordon model is well established and has been used extensively to investigate the spatial and temporal variability in lake-water balance in remote boreal regions of Canada (e.g. Wolfe et al., 2007; Bouchard et al., 2013; Tondu et al., 2013; Turner et al., 2014a, b). However, precipitation and groundwater often display similar isotopic signatures, as they both tend to retain their original isotopic composition because they undergo little to no evaporation (Gibson and Edwards, 2002; Gibson et al., 2008; Yi et al., 2008). This makes the distinction of the relative influence of groundwater and precipitation in lake-water balance challenging. Given this, the combination of chemical and isotopic approaches has the ability to produce more reliable interpretations, especially if the two approaches converge on a mutually reinforcing interpretation. Chemical and isotopic tracers have been widely used together to investigate the connectivity between groundwater and lake water within a single lake (e.g. Labaugh et al., 1997; Schuster et al., 2003; Rautio and Korkka-Niemi, 2011) or for a cluster of a few selected lakes (e.g. Katz et al., 1997; Gurrieri and Furniss, 2004; Turner and Townley, 2006; Arnoux et al., 2017a, b). Nonetheless, studies that have combined chemical and isotopic approaches to investigate the connectivity between groundwater and lake water at the landscape level and for a large number of lakes in a region are lacking.

The main objective of this study is to examine the importance of landscape position on groundwater-lake connectivity (i.e. the exchange of water between the groundwater system and the lakes) by scrutinizing both water chemistry and isotopic composition of water in a boreal esker complex in northeastern Ontario. The use of water tracers was preferred to direct measurements because tracers (i) have proven to be good indicators of interactions between groundwater and lake water and (ii) constitute a time- and cost-effective approach that can be applied at a large spatial scale. In this paper, the term "water tracer" defines natural indicators that provide information on water sources (conservative tracers) and water pathways (non-conservative tracers). Investigating such interactions in the context of esker hydrology is particularly relevant, as eskers consist of porous and permeable materials that facilitate groundwater flows, are widespread in boreal regions (Smerdon et al., 2005; Ala-aho et al., 2015b), and constitute one of the most common types of aquifers for community water supplies in boreal regions of the globe (Cloutier et al., 2007; Okkonen and Kløve, 2011; Rey et al., 2018). Results from this study will be used to develop a lake typology (i.e. a classification or generalization of lakes into categories) of hydrological connectivity (Newton and Driscoll, 1990; Bertrand et al., 2014). The resultant typology will provide insights into lakes' sensitivity to environmental stressors, such as climate change, acidification or pollution, by accounting for variation among lake types through continuous monitoring. This classification will also improve and simplify water management and conservation, goals as each lake type requires similar management strategies in a region where cottage development, recreational fishing, forest operations, mining activities and aggregate extraction are prevalent (Cochrane, 2006; Rey et al., 2018). Additionally, the typology will provide an important baseline for comparison to future hydrological regimes that may alter them and be used for site selection and interpretations of past hydrological changes from stratigraphic analysis of isotopic and geochemical indicators in sediment cores from lakes. Finally, the sensitivity of the proposed typology will be assessed by investigating whether short-term variations of lake-water characteristics are more readily detected in higher-elevation 
groundwater-recharge lakes (i.e. lakes that receive the majority of their water from precipitation and feed the groundwater system) in comparison to lower-elevation groundwaterdischarge lakes (i.e. lakes that receive the majority of their water from groundwater).

\section{Study area}

The study area is a portion of the kettle lake esker between the southern shore of Frederick House Lake and the northern shore of Night Hawk Lake, a region located approximately $35 \mathrm{~km}$ east of Timmins, Ontario, Canada (Fig. 1a). The Timmins region is characterized by a humid continental climate ("dfb" in the Köppen climate classification), with a mean annual temperature of $1.8^{\circ} \mathrm{C}$ and average precipitation of $835 \mathrm{~mm}$ (Environment Canada, 2015). This region has long cold winters, and lakes are covered with ice from early November until early April. Summers are usually wet, and mean air temperatures are $17.5^{\circ} \mathrm{C}$ in July. Many of the study lakes and streams are located within Kettle Lakes Provincial Park as well as in lower-elevation regions that have been moderately influenced by human activities (Cochrane, 2006). The study region is covered with well-drained orthic humo-ferric podzols, while surrounding clay plains are for the most part covered with moderately to poorly drained orthic grey luvisols and gleyed grey luvisols (Ontario Ministry of Northern Development and Mines, 2006). Jack pine (Pinus banksiana), poplar (Populus tremuloides), black spruce (Picea mariana), white birch (Betula papyrifera), trembling aspen (Populus tremuloides) and balsam fir (Abies balsamea) dominate the well-drained areas, with a dominance of spruce in poorly drained regions.

The regional landscape is dominated by landforms and deposits created by the Laurentide Ice Sheet during the last glacial maximum and subsequent deglaciation approximately 10000 years ago (Dyke, 2004). The ablation of the ice sheet was particularly dynamic and led to the formation of relatively large eskers composed of long sinuous ridges of coarse-grained glaciofluvial sediments in deposits oriented in a north-south direction and mantling the crystalline bedrock (Cloutier et al., 2007; Rey et al., 2018). The retreat of the ice sheet was accompanied by ponding of glacial meltwaters that led to the development of glacial Lake Ojibway, which submerged most of the region (Roy et al., 2011), and the widespread deposition of glaciolacustrine clay, followed by the drainage of Lake Ojibway into Hudson Bay 8200 years ago (Roy et al., 2011). As Lake Ojibway levels dropped, wave action eroded the surface of the esker and redistributed some sand materials on the flanks on the esker, forming lateral littoral sand units that drape the glaciolacustrine clays (Cloutier et al., 2007; Rey et al., 2018; Fig. 1b). The numerous kettle lakes on the esker formed as glacial ice that was trapped in the outwash materials melted.
The esker stratigraphy ensures that its groundwater system is highly localized because the esker generally has a high hydraulic conductivity due to its coarse texture. The esker is surrounded by underlying bedrock and the adjacent fine-grained glaciolacustrine deposits, both characterized by very low hydrological conductivity (Stauffer and Wittchen, 1992). As a consequence, the esker can be conceptually partitioned into zones of unconfined aquifers in its centre, where coarse material is present at the surface, and zones of confined aquifers at its edges, where fine-grained sediment mantles the core of the esker (Fig. 1b; Cloutier et al., 2007; Rey et al., 2018). Thus, the recharge of the esker will occur through infiltration of precipitation in the unconfined aquifer, and discharge will take place on the esker flanks at the contact of the clay, where most groundwater springs emerge (Cloutier et al., 2007; Rey et al., 2018). Confined aquifers found on the surrounding clay plain are often covered by peatlands and shallow lakes fed by groundwater springs on the edges of the esker or by streams that drain the esker (Rossi et al., 2012).

\section{Methods}

\subsection{Geomatic and lake morphometric data}

Lakes and other geographic features were digitized from Google Earth using the imagery dating from 26 July 2005. Maximum lake depths $\left(Z_{\max }\right)$ were obtained from the Ontario Ministry of Natural Resources and Forestry (OMNRF, 2011). Digital elevation models (DEMs) from the study area were obtained from Natural Resources Canada (2019), with a spatial resolution of $20 \mathrm{~m}$ (NRC, 2013). Lake elevation values were calculated as the mean elevation of the lake in ArcGIS 10.3 from the available DEM, and a proxy of lake watershed slopes was calculated from the DEM in ArcGIS in a $100 \mathrm{~m}$ buffer zone surrounding each lake and termed the perimeter slope. This approach was used because of the coarse spatial resolution of the DEM, and the close proximity of the lakes made clear individual lake watershed delineation impossible. Because all lakes in the study area are kettle lakes, which are characterized by steep shore slopes, initial buffer zones of different widths were produced. The buffer width of $100 \mathrm{~m}$ was chosen, as this distance showed the best correlation with water tracers.

\subsection{Field measurements and water sample collection}

Water samples were collected during three field campaigns (7-14 June 2013, 16-23 June 2014 and 12-19 August 2014). 50 lakes were sampled $(29,28$ and 50 lakes during the June 2013, June 2014 and August 2014 campaigns respectively) as well as a number of streams (lake outlets and lake inlets) and groundwater springs. The lakes were chosen to achieve a wide spatial coverage over this region, encompassing a gradient of lake elevations as well as lake types. A few lakes located in the area of interest could not be sampled due 
(a)
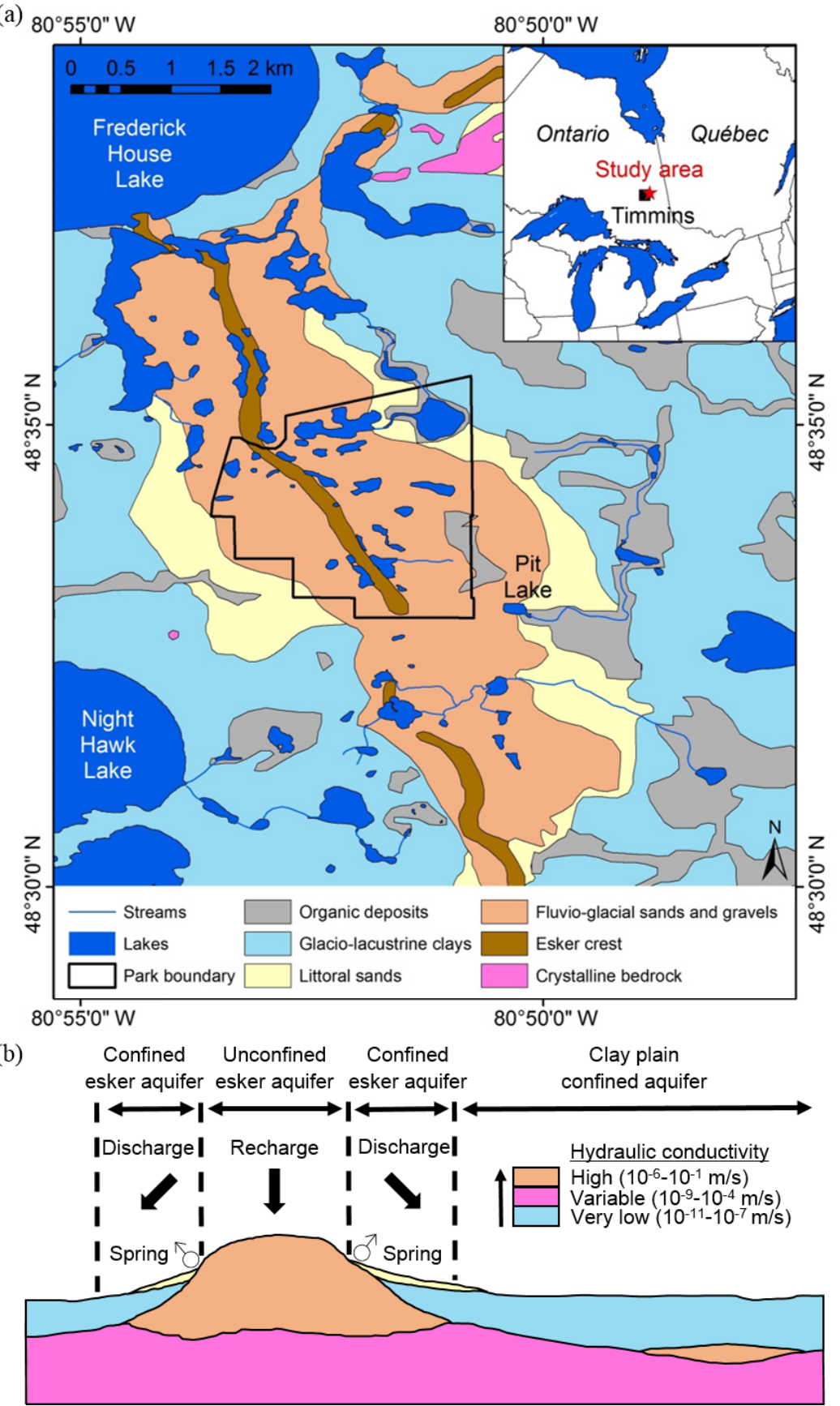

Figure 1. Location of the study area in northeastern Ontario near Timmins, Ontario (based on Richard and McClenaghan, 2000; (C) Queen's Printer for Ontario, 2021) (a), and conceptual geological transverse section of an esker complex at latitude $48^{\circ} 35^{\prime} 0^{\prime \prime} \mathrm{N}$ (b) (figure modified from Cloutier et al., 2007; hydraulic conductivity values from Cloutier et al., 2013).

to poor accessibility. Groundwater springs and streams flowing into the study lakes were also sampled to characterize the interactions between local groundwater and lakes.

Temperature and specific conductance of the water (corrected to $25^{\circ} \mathrm{C}$ ) at each site were measured with an YSI Salinity, Conductivity and Temperature meter (accuracy $\pm 0.1 \mu \mathrm{S} \mathrm{cm}^{-1}$ and $\pm 0.1^{\circ} \mathrm{C}$ ). The $\mathrm{pH}$ was measured with an
UP-5 Denver Instrument pH meter calibrated before usage (accuracy \pm 0.1 ). Water samples were collected using $1 \mathrm{~L}$ Nalgene bottles that were triple rinsed with distilled water prior to use and again with sample water while sampling (Louiseize et al., 2014). To prevent cross-contamination, the triple rinsing of bottles with sampling water was conducted from the final sampling point in the lake or downstream of 
stream and spring sampling points. Bottles were completely filled in order to avoid headspace air and subsequently filtered within $3 \mathrm{~h}$ of sampling.

Samples collected for the water stable isotope, dissolved ion analysis and dissolved inorganic nitrogen were vacuum filtered with $0.45 \mu \mathrm{m}$ Millipore Isopore filters. Vacuum filtering apparatuses were triple rinsed with distilled water and the lake water before and after use for each sample. The filtrates were then poured and placed into pre-cleaned $20 \mathrm{~mL}$ plastic scintillation vials. Three replicates were collected for each sample. All vials were previously rinsed with filtered sample water that was discarded. Vials were completely filled to avoid any headspace, sealed with Parafilm ${ }^{\mathrm{TM}}$ to avoid evaporation, and kept in a cool and dark fridge prior to analysis.

Samples for total dissolved nitrogen (TDN), dissolved organic carbon (DOC) and dissolved inorganic carbon (DIC) analysis were filtered on-site using a glass filtration and Whatman GF/F glass fibre filters to avoid any ex situ carbon addition. Filters were pre-ashed at $550^{\circ} \mathrm{C}$ for $2 \mathrm{~h}$ and wrapped with pre-ashed aluminium foil prior to utilization to eliminate any residual organic matter. The glass filtration apparatus was triple rinsed with distilled water and lake water before and after use for each sample and was wrapped with new clean pre-ashed aluminium foil overnight. Filtrates were then poured and stored into pre-cleaned $45 \mathrm{~mL}$ amber EPA vials with Teflon-lined septa with no headspace (Louiseize et al., 2014). Two replicates were collected for each sample. Vials were labelled and were kept cool and in the dark in a fridge prior to analysis.

\subsection{Laboratory analysis}

The stable isotope ratios of water $\left(\delta^{18} \mathrm{O}\right.$ and $\left.\delta^{2} \mathrm{H}\right)$ were measured using a Los Gatos Research Liquid-Water Isotope Analyzer (LGR) in the FaBRECC laboratory at Queen's University, which vaporizes an injected sample and measures its absorbance relative to Vienna Standard Mean Ocean Water (\%० V-SMOW). All runs contain six replicate analyses and three standards produced by Los Gatos bracketing every three samples (e.g. LGR1A $-\delta^{18} \mathrm{O}=-19.50 \%$ and $\delta^{2} \mathrm{H}=-154.3 \%$; LGR2A $-\delta^{18} \mathrm{O}=-16.14 \% \circ$ and $\delta^{2} \mathrm{H}$ $=-123.6 \%$; LGR3 $\mathrm{A}-\delta^{18} \mathrm{O}=-13.10 \%$ and $\delta^{2} \mathrm{H}=$ $-96.4 \%$; LGR4A $-\delta^{18} \mathrm{O}=-7.69 \%$ and $\delta^{2} \mathrm{H}=-51.0 \%$; LGR5A $-\delta^{18} \mathrm{O}=-2.80 \%$ and $\delta^{2} \mathrm{H}=-9.5 \%$ ). Sample reproducibility $(1 \sigma)$ was based on repeated measurements of samples and standards fixed at $0.25 \%$ for $\delta^{18} \mathrm{O}$ and at $1.5 \%$ 。 for $\delta^{2} \mathrm{H}$.

Concentrations of inorganic ions $(\mathrm{Ca}, \mathrm{Mg}, \mathrm{K}, \mathrm{Na}, \mathrm{Cl}$ and $\mathrm{SO}_{4}$ ) were measured by liquid ion chromatography with a Dionex ICS-3000. Detection limits were as follows: $0.5 \mathrm{ppm}$ for $\mathrm{Ca}, 0.01 \mathrm{ppm}$ for $\mathrm{Mg}, 0.2 \mathrm{ppm}$ for $\mathrm{K}, 0.3 \mathrm{ppm}$ for $\mathrm{Na}$, $0.05 \mathrm{ppm}$ for $\mathrm{Cl}$ and $0.1 \mathrm{ppm}$ for $\mathrm{SO}_{4}$. Concentrations of dissolved inorganic species $\left(\mathrm{NO}_{2}-\mathrm{NO}_{3}\right.$ and $\left.\mathrm{NH}_{4}\right)$ were measured by colourimetry using an Astoria Pacific FASPac II Flow Analyzer (detection limits of $0.01 \mathrm{ppm}$ ). Concentra- tions of DOC, DIC and TDN were measured by hightemperature combustion and nondispersive infrared sensor and chemiluminescent detection using a Shimadzu TOCVPCH/TNM equipped with a high-sensitivity catalyst system (detection limits of $0.08 \mathrm{ppm}$ for DOC and $0.015 \mathrm{ppm}$ for total nitrogen (TN; Louiseize et al., 2014). Total dissolved carbon (TDC) was calculated as the sum of DOC and DIC.

\subsection{Water balance calculations}

Monthly precipitation isotopic data are available from February 1997 to November 2010. Precipitation isotopic data were collected at Bonner Lake, about $125 \mathrm{~km} \mathrm{NW}$ of the study area, by the Canadian Network for Isotopes in Precipitation (CNIP; Birks et al., 2015). The general water (Eq. 1) and isotope balance (Eq. 2) of a well-mixed lake may be written respectively as (Darling et al., 2005)

$$
\begin{aligned}
& \frac{\mathrm{d} V}{\mathrm{~d} t}=I-Q-E, \\
& \frac{V \mathrm{~d} \delta_{\mathrm{L}}+\delta_{\mathrm{L}} \mathrm{d} V}{\mathrm{~d} t}=I \delta_{\mathrm{I}}-Q \delta_{\mathrm{Q}}-E \delta_{\mathrm{E}},
\end{aligned}
$$

where $V$ is the volume of the lake; $t$ is time; $\mathrm{d} V$ is the change of volume over time $\mathrm{d} t ; I$ is instantaneous inflow where $I=I_{\mathrm{F}}+I_{\mathrm{G}}+P$ (with $I_{\mathrm{F}}$ being surface inflow, $I_{\mathrm{G}}$ groundwater inflow and $P$ precipitation on the lake surface); $Q$ is instantaneous outflow where $Q=Q_{\mathrm{R}}+Q_{\mathrm{G}}\left(Q_{\mathrm{R}}\right.$ is surface outflow and $Q_{\mathrm{G}}$ is groundwater outflow); $E$ is evaporation; and $\delta_{\mathrm{L}}, \delta_{\mathrm{I}}, \delta_{\mathrm{Q}}$ and $\delta_{\mathrm{E}}$ are the isotopic compositions of the lake, inflow, outflow and evaporative flux respectively. Assuming (i) that the lake maintains a near-constant volume in the long term (i.e. $\mathrm{d} V=0$ and $\mathrm{d} t \rightarrow \infty$; Darling et al., 2005) and (ii) that physical outflow does not cause isotopic fractionation (i.e. $\delta_{\mathrm{Q}}=\delta_{\mathrm{L}}$; Gibson and Edwards, 2002; Yi et al., 2008), Eqs. (1) and (2) can be simplified and rewritten as follows:

$I=Q+E$,

$I \delta_{\mathrm{I}}=Q \delta_{\mathrm{Q}}+E \delta_{\mathrm{E}}$.

$E$ can be related to $I$, assuming that the lakes are in isotopic steady state (i.e. undergoing evaporation while maintaining constant volume). This assumption seems well justified, as most of the lakes have had enough time in the past to reach their isotopic steady state, which is reflective of the local climate and their mean hydrological status and can be defined by its water balance, which corresponds to the ratio of the total inflow to the evaporation rate (Isokangas et al., 2015). The evaporation-to-inflow ratio of the lake $E_{\mathrm{L}} / I_{\mathrm{L}}$ can be calculated by combining Eqs. (3) and (4) (Gibson and Edwards, 2002; Yi et al., 2008): 
$\frac{E_{\mathrm{L}}}{I_{\mathrm{L}}}=\frac{\delta_{\mathrm{I}}-\delta_{\mathrm{L}}}{\delta_{\mathrm{E}}-\delta_{\mathrm{L}}}$,

where $\delta_{\mathrm{I}}$ was computed as the intersection of the local meteoric water line (LMWL) with the local evaporation line (LEL; Gibson et al., 1993; Yi et al., 2008). $\delta_{\mathrm{L}}$ is the isotopic composition of the lake-water sample, and $\delta_{\mathrm{E}}$ was estimated using the Craig-Gordon model (Craig and Gordon, 1965) formulated by Gonfiantini (1986) as follows:

$\delta_{\mathrm{E}}=\frac{\left(\delta_{\mathrm{L}}-\varepsilon^{*}\right) / \alpha^{*}-h \delta_{\mathrm{A}}-\varepsilon_{k}}{1-h+\varepsilon_{k}}$,

where $\delta_{\mathrm{L}}$ is the isotopic composition of lake water, $\varepsilon^{*}$ is the equilibrium isotopic separation term, $\alpha^{*}$ is the liquid-vapour equilibrium fractionation factor, $h$ is the relative humidity, $\delta_{\mathrm{A}}$ is the isotopic composition of the local atmospheric moisture, and $\varepsilon_{k}$ is the kinetic separation term between the liquid and vapour phases. The $\varepsilon^{*}$ and $\alpha^{*}$ parameters which are temperature dependent can be calculated using empirical equations for $\delta^{18} \mathrm{O}$ as follows (Horita and Wesolowski, 1994):

$$
\begin{aligned}
\varepsilon^{*}= & -7.685+6.7123\left(\frac{10^{3}}{T}\right)-1.6664\left(\frac{10^{6}}{T^{2}}\right) \\
& +0.35041\left(\frac{10^{9}}{T^{3}}\right), \\
\alpha^{*}= & \exp \left(-\frac{7.685}{\times} 10^{3}+\frac{6.7123}{T}-\frac{1666.4}{T^{2}}+\frac{350410}{T^{3}}\right),
\end{aligned}
$$

where $T$ is the air temperature in kelvins. $\varepsilon_{k}$ (Eq. 9) is expressed for $\delta^{18} \mathrm{O}$ by (Gonfiantini, 1986)

$\varepsilon_{k}=(0.0142(1-h)) 1000$.

The equation for $\delta_{\mathrm{E}}$ was modified according to Gibson and Edwards (2002) to directly utilize isotopic data in per mil rather than as a decimal fraction and expressed as follows:

$\delta_{\mathrm{E}}=\frac{\alpha^{*} \delta_{\mathrm{L}}-h \delta_{\mathrm{A}}-\varepsilon}{1-h+10^{-3} \varepsilon_{k}}$,

where $\varepsilon$ is the total isotopic separation factor that includes both $\varepsilon^{*}$ and $\varepsilon_{k}$, expressed as

$\varepsilon=\varepsilon^{*}+\varepsilon_{k}$.

$\delta_{\mathrm{A}}$ was originally estimated with the original model that assumes isotopic equilibrium between atmospheric moisture and precipitation as follows (Gibson, 2002):

$\delta_{\mathrm{A}}=\frac{\delta_{\mathrm{P}}-\varepsilon^{*}}{1+10^{-3} \varepsilon^{*}}$,

where $\delta_{\mathrm{P}}$ was computed as the average isotopic composition of annual precipitation from February 1997 to November 2010 (data collected by CNIP). The same procedure was used to calculate the evaporation-to-inflow ratio of streams and groundwater springs for comparison, although the assumptions of the methodology can only be applied to lakes.

However, the hypothesis of the steady state may not be valid for some small lakes that undergo significant changes in lake levels as evaporation progresses. For those lakes in non-steady state (here defined as non-alkaline high-elevation lakes), the evaporative loss fraction of the lake volume $(f)$ was calculated using the original equation of Gonfiantini (1986), rearranged as follows (Skrypek et al., 2015):

$f=1-\left[\frac{\delta_{\mathrm{L}}-\delta^{*}}{\delta_{\mathrm{p}}-\delta^{*}}\right]^{\frac{1}{m}}$

where $\delta_{\mathrm{p}}$ is the initial value of water in the lake that undergoes evaporation, $\delta_{\mathrm{L}}$ the final value of water in the lake that undergoes evaporation, $\delta^{*}$ is the limiting isotope enrichment factor, defined as (Skrypek et al., 2015)

$\delta^{*}=\frac{h \delta_{\mathrm{A}}+\varepsilon}{h-\frac{\varepsilon}{1000}}$,

and $m$ is the enrichment slope, defined as (Skrypek et al., 2015)

$m=\frac{h-\frac{\varepsilon}{1000}}{h+\frac{\varepsilon_{k}}{1000}}$.

While $E / I$ ratios and $f$ values are two metrics calculated with different formulas, they can be compared equivalently, as they both represent the mass balance of the lakes in dimensionless ratios of water losses versus available lake water.

\subsection{Numerical analysis}

Linear regressions were used to assess the degree of covariability between quantitative variables, while logistic regressions were utilized to assess the relations between binary variables and quantitative variables at the 0.05 level. Breakpoint analysis or segmented regression was used to detect any change of trends in water tracers along an elevation gradient and to produce subsequent higher-level groupings of lakes. Break points that were significant at the 0.05 level were averaged to obtain the elevation of the "breakpoint line". A nonmetric multidimensional scaling (NMDS) was run to assess the differences among lake types in a 2-D ordination space using non-scaled values of electrical conductance (EC), Ca, $\delta^{18} \mathrm{O}$ and $\delta^{2} \mathrm{H}$ as input variables and Euclidean distance as a measure of dissimilarity. A Wilcoxon signed-rank test was subsequently applied as a post hoc analysis for all lake-water variables that were above detection limits to determine if differences among the different types of lakes were statistically significant at the 0.05 level, as most of the Shapiro-Wilk tests for normality revealed that most variables were not normally distributed. An analysis of similarity (ANOSIM) was also carried out as a complement to determine if within-group 

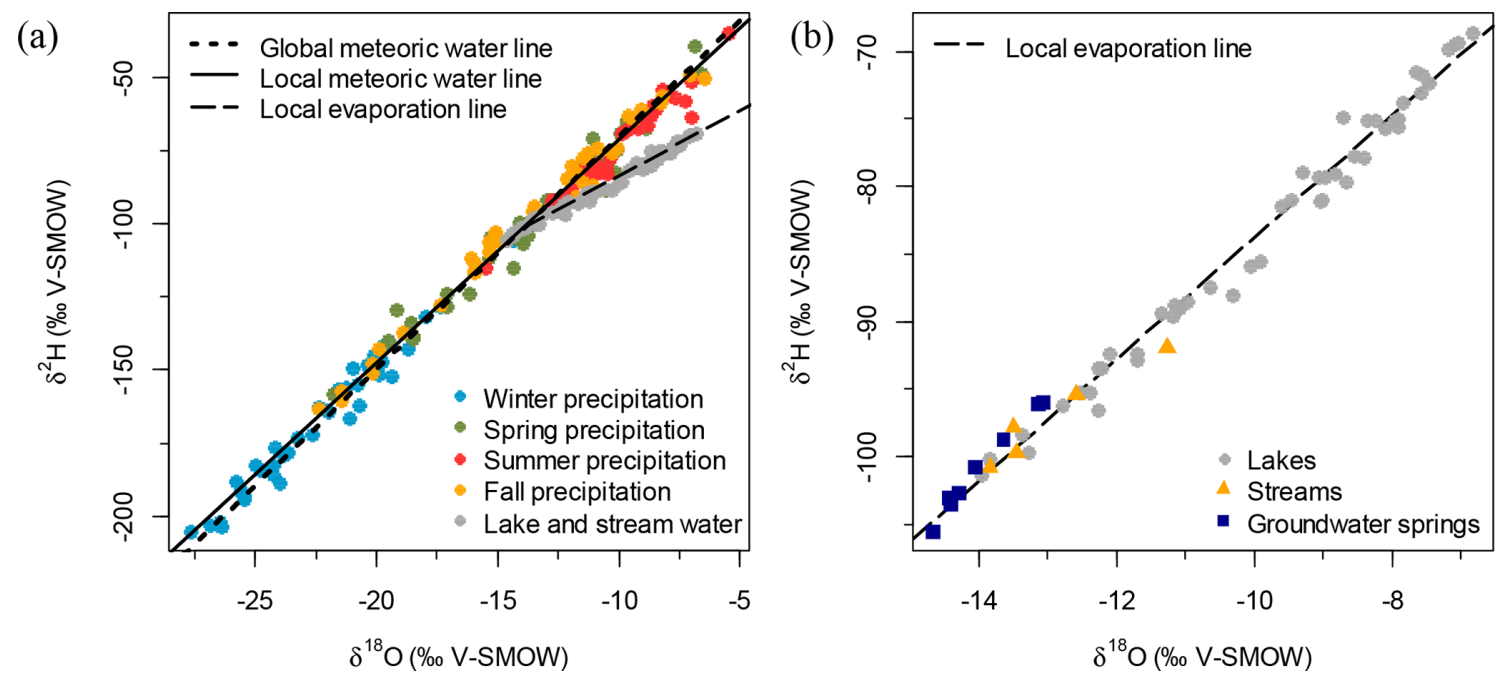

Figure 2. Isotopic composition of precipitation in relation to the global meteoric water and local meteoric water lines $(r=0.99, n=166$ and $p<0.001)$ (a), and isotopic composition of collected water samples in relation to the local evaporation line $(r=0.99, n=68$ and $p<0.001)$ (b).

similarity was significantly greater than in-between group similarity at the 0.05 level. All statistical analyses were performed in $R 3.4$ on the data from the August 2014 campaign, as it was the one with the most samples.

\section{Results}

\subsection{Temperature and water stable isotopes}

During the August 2014 field campaign, all types of bodies of water differed from one another by their temperature: springs were characterized by low temperatures $\left(6-12^{\circ} \mathrm{C}\right)$, streams had slightly higher temperatures $\left(12-16^{\circ} \mathrm{C}\right)$ and lakes ranged from 16 to $18^{\circ} \mathrm{C}$. It should be noted however that spring temperature is not an accurate indication of groundwater temperature due to alterations induced by the velocity of the discharging spring and the resulting warming of the discharging water as it reaches the surface.

Monthly precipitation isotopic data from CNIP from February 1997 to November 2010 from Bonner Lake, about $125 \mathrm{~km} \mathrm{NW}$ of the study area, show progressive enrichment in values between winter, spring, fall and summer on the global and local meteoric water lines, which are similar (Fig. 2a). The water samples (i.e. groundwater springs, streams and lakes) displayed a wide range of isotope values $\left(-14.7\right.$ to $-6.8 \%$ o for $\delta^{18} \mathrm{O}$ and -105.5 to $-68.6 \%$ for $\left.\delta^{2} \mathrm{H}\right)$, which fell on a local evaporation line $(r=0.99$ and $p<0.001$; Fig. 2b). Groundwater springs have isotopic values similar to mean annual precipitation $(-14.7$ to $-13.1 \%$ o for $\delta^{18} \mathrm{O}$ and 105.5 to $-96.0 \%$ for $\delta^{2} \mathrm{H}$ ) while being more depleted, as summer precipitation is more enriched in heavy isotopes than groundwater (Fig. 2a). Streams have comparable isotopic composition to groundwater springs $(-13.8$ to
$-11.3 \%$ for $\delta^{18} \mathrm{O}$ and -100.8 to $-91.9 \%$ for $\left.\delta^{2} \mathrm{H}\right)$. By contrast, lakes are characterized by large variations in water isotopic composition, ranging from values comparable to groundwater springs (ca. $-14 \%$ of $\delta^{18} \mathrm{O}$ and $-100 \%$ for $\delta^{2} \mathrm{H}$ ) to more enriched values (ca. $-6 \%$ for $\delta^{18} \mathrm{O}$ and $-70 \%$ o for $\left.\delta^{2} \mathrm{H}\right)$.

A significant correlation exists between $\delta^{18} \mathrm{O}$ and elevation ( $r=0.53, n=50$ and $p<0.001$; Fig. 3a), suggesting that elevation is an important variable explaining the isotopic composition of water in the study lakes. Lakes sampled at lower elevations are more depleted while lakes sampled at higher elevations are enriched in ${ }^{18} \mathrm{O}$ and ${ }^{2} \mathrm{H}$. Another significant correlation occurs between $\delta^{18} \mathrm{O}$ and the steepness of the slopes surrounding the lake $(r=-0.33, n=48$ and $p=0.02$ ), which suggests that morphometric factors may also influence lake-water balance.

Evaporation-to-inflow ratio calculations $(E / I)$ and evaporative loss fractions of the lake volume $(f)$ show that groundwater springs and streams have $E / I$ ratios close to zero due to their short residence times, while lakes have $E / I$ or $f$ values ranging from values similar to groundwater springs and streams to near $E / I$ or $f \sim 1$, owing to their longer residence times that expose them to evaporation (Fig. 4a).

\subsection{Solutes and dissolved organic matter}

As is the case with stable isotope values, water bodies reveal a wide range for non-conservative ions and the overall sum of ions indicated by lake-water specific conductance, all of which are significantly correlated (see correlation matrix; Table A1). Groundwater springs have the highest specific conductance $\left(300-550 \mu \mathrm{S} \mathrm{cm}^{-1}\right)$, while streams have values ca. $300 \mu \mathrm{S} \mathrm{cm}^{-1}$. Lakes show a wide range of solute con- 


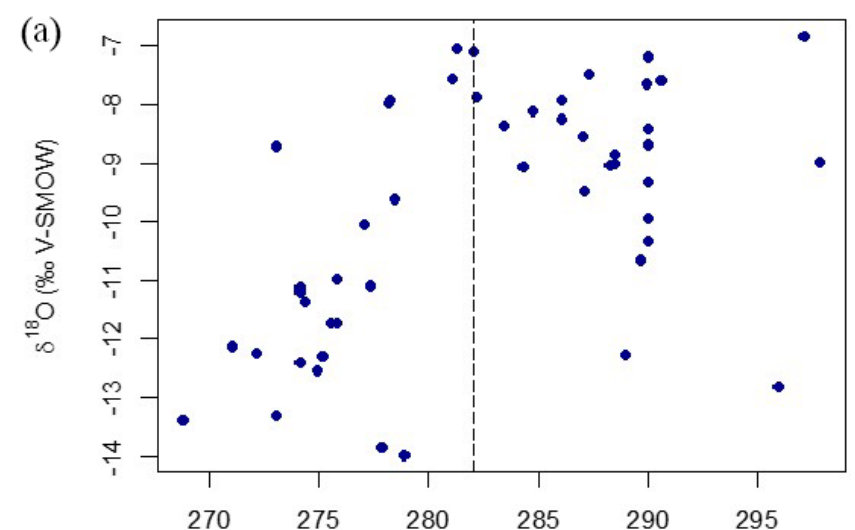

(b)

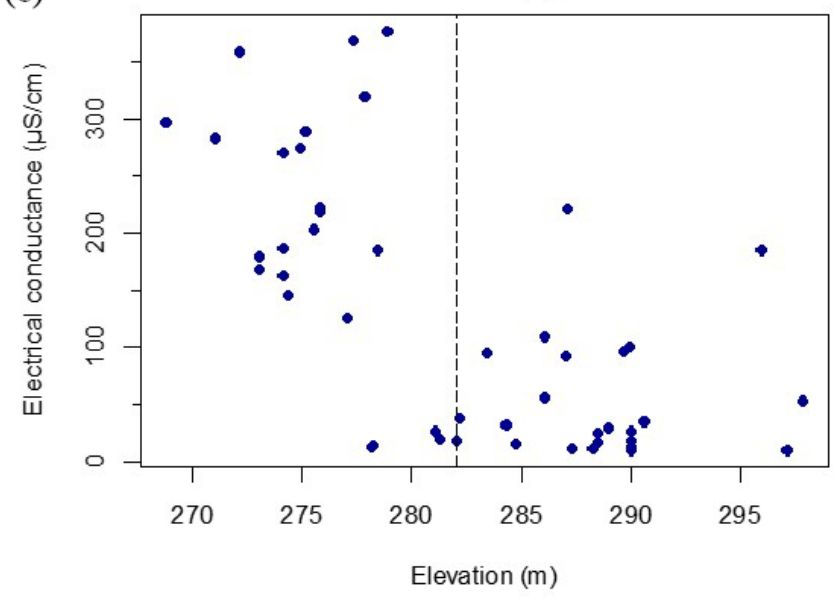

Figure 3. Relation between $\delta^{18} \mathrm{O}$ in water samples and elevation ( $r=0.53, n=50$ and $p<0.001)$ (a) and between specific conductance and elevation $(r=-0.67, n=50$ and $p<0.001)$ (b). The horizontal dashed line indicates the position of a breakpoint analysis, which occurs at an elevation of $\sim 282 \mathrm{~m}$ a.s.l. in both cases (Table 1).

tent and values of specific conductance, from values similar to groundwater springs (ca. $400 \mu \mathrm{S} \mathrm{cm}^{-1}$ ) to very low values similar to precipitation (as low as $10 \mu \mathrm{Scm}^{-1}$; Fig. 3b). A significant correlation exists between the specific conductance and elevation $(r=-0.67, n=50$ and $p<0.001)$, suggesting that elevation is an important variable explaining specific conductance in lakes. There was also a significant relationship between the specific conductance and the ratio of the perimeter to surface area of the lakes $(r=0.48, n=48$ and $p<0.001)$, which suggests that lake morphology may also be important.

Only 36 lakes were sampled for DOC and TN. Unlike nonconservative ions and conservative isotopic tracers, no significant correlations were found between dissolved organic elements or TN and elevation $(r=-0.04, n=36$ and $p=0.84$ for DOC; $r=0.05, n=36$ and $p=0.77$ for TN). However, significant or marginally significant correlations were observed (i) between DOC and the perimeter-to-area ratio
Table 1. Results showing significant break points in nine waterchemistry variables and lake elevation (lower and upper elevation ranges represent the standard deviation).

\begin{tabular}{lrrr}
\hline $\begin{array}{l}\text { Environmental } \\
\text { variable }\end{array}$ & $\begin{array}{r}\text { Mean } \\
\text { elevation }\end{array}$ & $\begin{array}{r}\text { Lower } \\
\text { elevation }\end{array}$ & $\begin{array}{r}\text { Upper } \\
\text { elevation }\end{array}$ \\
\hline$\delta^{18} \mathrm{O}$ & 282 & 280 & 284 \\
$\delta^{2} \mathrm{H}$ & 282 & 280 & 284 \\
$d^{*}$ & 282 & 280 & 284 \\
$\mathrm{EC}$ & 284 & 281 & 287 \\
$\mathrm{Ca}^{2+}$ & 284 & 282 & 287 \\
$\mathrm{Mg}^{2+}$ & 282 & 280 & 284 \\
$\mathrm{~K}^{+}$ & 282 & 278 & 285 \\
$\mathrm{DIC}$ & 282 & 280 & 283 \\
$\mathrm{TC}$ & 282 & 280 & 283 \\
\hline Breakpoint line & 282 & & \\
\hline
\end{tabular}

$* d$ corresponds to deuterium excess.

( $r=0.54, n=33$ and $p<0.001)$, with more elongated lakes having higher concentrations of DOC, and between (ii) DOC and mean lake depth, with deeper lakes having lower concentrations of DOC ( $r=-0.58, n=25$ and $p=0.11)$. A similar pattern was observed between $\mathrm{TN}$ and the perimeter-toarea ratio $(r=0.60, n=33$ and $p=0.002)$ and between $\mathrm{TN}$ and mean lake depth $(r=-0.71, n=25$ and $p=0.02)$.

\subsection{Correlations between water tracers}

There is a strong and significant correlation between lakewater isotopic values and specific conductance $(r=0.80$, $n=50$ and $p<0.001)$. However, the breakpoint analysis detects a distinct transition between similar values found in higher- and lower-elevation lakes, indicating a step-wise change in both specific conductance and $\delta^{18} \mathrm{O}$ with elevation. $\delta^{18} \mathrm{O}(r=0.35, n=27, p=0.08)$ (Fig. 3a) and electrical conductance $(r=0.00, n=27, p=0.65)$ (Fig. 3b) of the lakes located above $282 \mathrm{~m}$ a.s.l. do not display any relationship with elevation, nor does specific conductance $(r=0.36$, $n=23, p=0.10$ ) of the lakes located below $282 \mathrm{~m}$ a.s.l. Only $\delta^{18} \mathrm{O}$ of the lakes located below $282 \mathrm{~m}$ a.s.l. shows a significant relationship with elevation $(r=0.46, n=23$, $p=0.03$ ). This supports the assumption that the relationship between water tracers and elevation is mainly driven by the existence of two sets of lakes distinguished by the elevation of $282 \mathrm{~m}$ a.s.l. Nine available environmental variables had a statistically significant break point (i.e. an area of the line where the relationship between the variables changes trends) when regressed over elevation, and significant break points were within a narrow range of elevation, with a mean of $282 \mathrm{~m}$ a.s.l. (Table 1).

To further assess differentiation of the lakes in terms of conservative and non-conservative water tracers, an NMDS based on these factors was undertaken, with lakes above an 
(a)

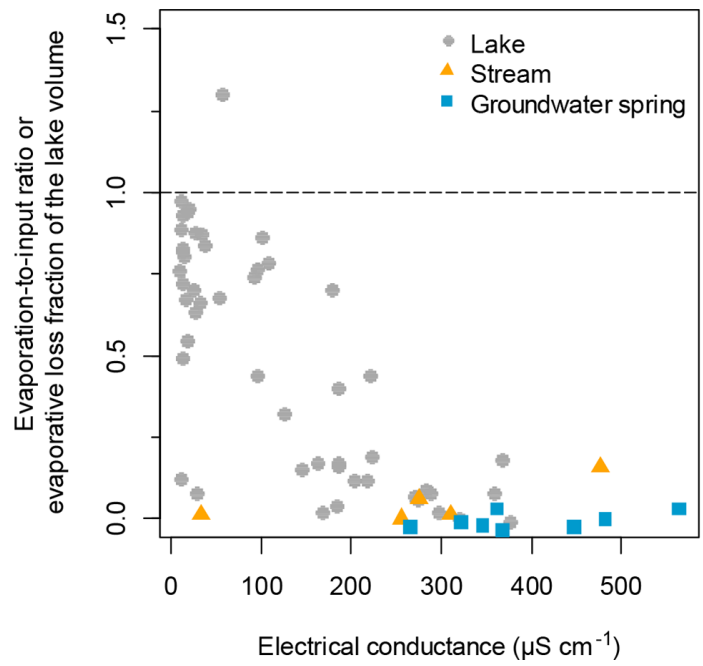

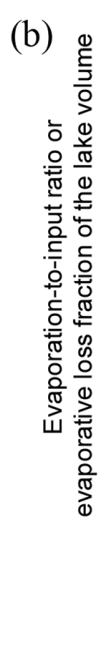

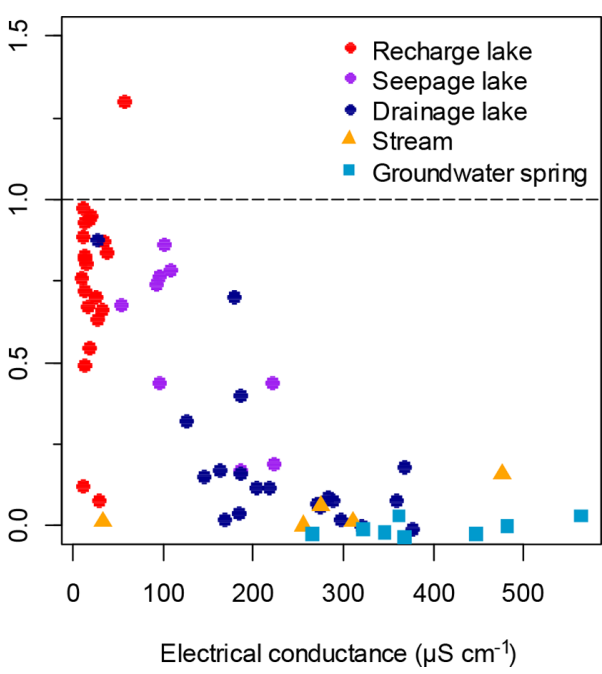

Figure 4. Relation between electrical conductance and calculated evaporation-to-inflow ratios. Lakes in panel (b) are coded according to a classification scheme developed in this paper.

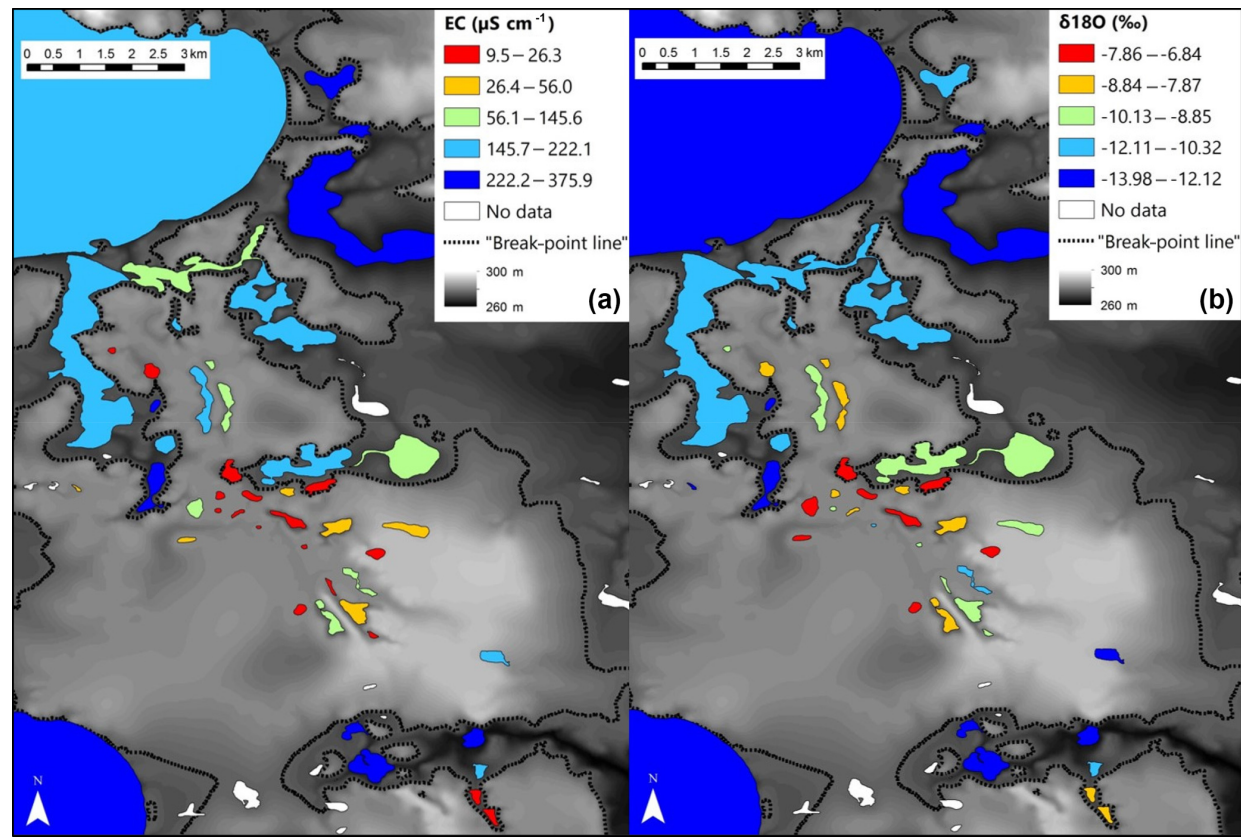

Figure 5. Spatial depiction between elevation and lake-water-specific conductance $\left(\mu \mathrm{S} \mathrm{cm}^{-1}\right)(\mathbf{a})$ and lake-water $\delta^{18} \mathrm{O}(\%)$ (b). The elevation of the breakpoint line $(284 \mathrm{~m})$ is shown as a dashed line.

elevation of $282 \mathrm{~m}$ a.s.l. coded as groundwater-recharge lakes and lakes below $282 \mathrm{~m}$ a.s.l. coded as groundwater-discharge lakes, indicating good separation of the groups based on water geochemistry (Fig. 6a).

The existence of two distinctive types of lakes was used to develop a lake typology to explain changes in water biogeochemistry across the studied lakes. In order to better understand how water tracers vary in those two zones, individual Wilcoxon signed-rank tests were undertaken for all lakewater variables that were above detection limits (Table A2).
All anions and cations (and correlated variables including specific conductance), with the exception of $\mathrm{K}$, were individually significantly different above and below an elevation of $282 \mathrm{~m}$ a.s.l. This was also the case of the isotopic variables. Variables that were not significantly different included $\mathrm{K}$ and TN.

\subsubsection{Short-term evolution of water tracers}

Short-term water balance variability was observed towards the end of the growing season in 2014 (Fig. A1b and d in the 

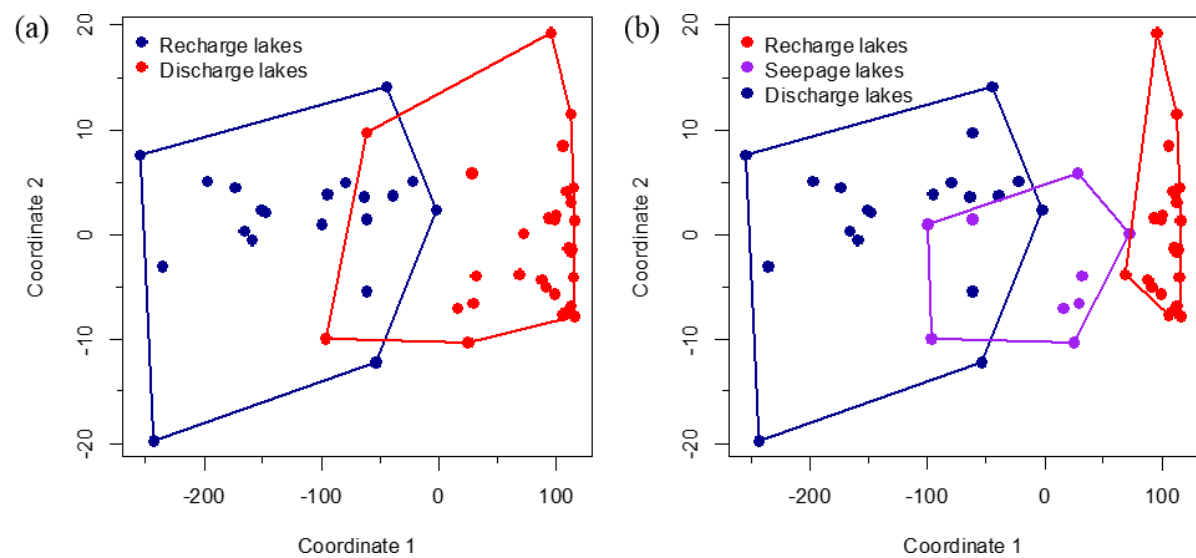

Figure 6. Non-metric multidimensional scaling (NMDS) applied to conservative and non-conservative water tracers. Lakes that occurred at an elevation greater than $282 \mathrm{~m}$ a.s.l. are labelled as "groundwater recharge" lakes, whereas lakes located at an elevation less than $282 \mathrm{~m}$ a.s.1. are labelled as "groundwater discharge" lakes (a). A third group of lakes (labelled "seepage") is further discerned based on chemical and isotopic characteristics (b). The model converged after 35 iterations. Stress value for the NMDS is low (stress $=0.023$ ).

Appendix) and between the sampling campaign of 2013 and 2014 (Fig. A2a and c). Lakes located at an elevation greater than $282 \mathrm{~m}$ a.s.l. underwent marked changes in water balance during the three sampling campaigns, whereas lakes located below $282 \mathrm{~m}$ a.s.l. underwent little or no change, especially the lower-elevation lakes (Fig. A2a and b). Similarly, the water-chemistry gradient between upland solute-poor lakes and lowland solute-rich lakes changed seasonally and between years. Lakes above $282 \mathrm{~m}$ a.s.l. did not respond chemically to short-term hydroclimatic change, while lakes below $282 \mathrm{~m}$ a.s.l. displayed significant solute changes (Fig. A2c and d).

\section{Discussion}

\subsection{Interpretation of water tracers}

The wide range of lake isotopic values and $E / I$ and $f$ ratios suggests that lakes on the esker are heterogeneous in terms of water balance and hydrological characteristics. Groundwater springs have the most depleted isotopic values because their water-residence times are short and they only undergo limited evaporation (Gazis and Feng, 2004; Rey et al., 2018). Streams display isotopic values similar to groundwater springs because they originate from groundwater and experience relatively low evaporation rates due to more continuous water flow. The wide range of isotopic values for lakes can be explained by their position in the landscape, particularly relative to their location in the esker aquifer system for which elevation appears to be a good proxy. This suggests that lowland lakes are primarily fed by groundwater inflow, while upland lakes receive a much lower contribution from the local groundwater in their respective water budgets. Nonetheless, it is challenging to distinguish the influence of groundwater from precipitation in lake-water balance, as they both have similar isotopic signatures (Fig. 2b; Gibson and Edwards, 2002; Gibson et al., 2008; Yi et al., 2008). Yet given (i) the small spatial scale the study was carried out on (i.e. a rectangular zone of $\sim 12 \mathrm{~km}$ by $\sim 6 \mathrm{~km}$ ), (ii) the close proximity of the lakes, (iii) the terrain homogeneity (with boreal forest as the dominant land cover), (iv) the limited topography, and (v) the strong correlation between water isotopes and specific conductance $(r=0.63, n=50$ and $p<0.001$ ), significant differences in precipitation patterns within the study area are unlikely. Therefore, groundwater connectivity is likely the main control on lake water balance. Lake isotopic values can also be influenced by the isotopic composition of surface inflowing waters. But those are mainly groundwater springs (which are made of groundwater), their volume is small in comparison to the lake volume and some of those streams are intermittent in the sense that they were not flowing during each of the three field campaigns. Thus, this influence is probably limited.

Similar patterns are observed with the major ions in water. Groundwater springs have the highest solute concentrations likely due to chemical processes associated with mineral surface exchanges and weathering (Ala-aho et al., 2013). Lakes, however, displayed a wide range of water chemistries and range from the high-solute characteristic of groundwater to values close to zero, typical of precipitation (Fig. 2), suggesting that the heterogeneity of lakes on the esker is a result of the degree to which they interact with groundwater. As with isotopic values, chemical composition of a given lake depends on elevation. Lakes sampled at lower elevation are higher in solutes; this indicates that lowland lakes reflect interaction with intermediate or regional groundwater flows subject to more mineral weathering and dissolution (Tóth, 1963). Upland lakes on the other hand reflect interaction with local groundwater flow paths with correspondingly reduced mineral weathering and dissolution (Tóth, 1963). There are 
only minor differences in terms of the relative solute composition among the samples, suggesting that the esker subsurface material is geochemically relatively homogeneous and reflects the carbonate-rich nature of the glaciofluvial outwash that makes up the esker (Cummings et al., 2011). The carbonate-rich sediment originates from Paleozoic carbonates of the sedimentary Hudson Platform ca. $150 \mathrm{~km}$ to the north and is localized to glacial surficial sediments (Roy et al., 2011).

Other characteristics of the lake water (temperature and dissolved organic matter) do not reflect the changes seen in the stable isotopes and ionic concentration. Water temperatures of groundwater springs are coolest because the temperature of groundwater is typically close to the mean annual temperature of the region, while lake-water temperature varies strongly with season. There is little difference in temperature between lakes, and this is mainly the result of lake morphology rather than its connection with cool groundwater, as lakes of smaller volumes have a lower thermal inertia than larger ones. Differences in dissolved organic content between the lakes are also a result of lake morphology, as smaller lakes tend to have higher concentrations because they mix more easily and receive greater inputs due to their high catchment-size-lake volume ratios (Knoll et al., 2015). However, upland lakes tend to have slightly higher amounts likely due to their higher water-residence times.

\subsection{Lake hydrological classification}

The correlation between lake water $\delta^{18} \mathrm{O}$ and specific conductance $(r=0.80, n=50$ and $p<0.001)$ shows that there is a clear relation between conservative water tracers (which are indicative of water source and evaporation) and nonconservative water tracers (which are indicative of water flow paths), signifying that lowland lakes will receive a significant portion of their water as groundwater flows and will geochemically reflect this origin, while upland lakes will receive most of their water through precipitation and will be geochemically dilute.

Consequently, the observed breakpoint elevation likely corresponds to an effective hydraulic separation between groundwater-recharge and discharge areas (Winter et al., 1998). This contrast between the contribution of groundwater flow is evident in the distribution of lake-water composition (Figs. 5 and A1). Lakes characterized by groundwater discharge are spatially distinct from higher-elevation lakes in the groundwater-recharge zone. Lake position has been used as a classification criterion in several studies (e.g. Winter, 1977; Born et al., 1979). Thus, upland lakes in the recharge zone are known as groundwater-recharge lakes or recharge lakes, and, conversely, lowland lakes in the discharge zone, also called the underflow zone, will be referred to as groundwater-discharge lakes or discharge lakes (Fig. 7; Winter et al., 1998). Because discharge lakes receive a substantial amount of water from groundwater, they are considered to be groundwater-fed or minerotrophic, whereas recharge lakes which receive the majority of their water from precipitation and feed the aquifer are said to be precipitationfed or ombrotrophic (Webster et al., 1996). NMDS (Fig. 6a) and the Wilcoxon signed-rank test (Table A2) analysis showed that all conservative and non-conservative tracers are statistically different between the discharge zone and the recharge zone, except for TN and K. The ANOSIM between the recharge and discharge lakes shows that within-group similarity is significantly greater than between-group similarity, as illustrated by a large and significant $r$ value $(r=0.77$, $n=50$ and significance of 0.001 on 1000 permutations).

A few solute-rich alkaline lakes are located in the groundwater-recharge zone, which is supposed to be depleted in solutes (Fig. 5a). Furthermore, the two primary groups in ordinal space display a small overlap (Fig. 6a), suggesting the existence of a third category of hybrid lakes referred to as seepage or flow-through lakes (Winter, 1976; Webster et al., 1996; Winter et al., 2003). In those lakes, water comes in as groundwater in-seepage and is returned to the groundwater system as out-seepage (Anderson and Munter, 1981). Seepage lakes can be found both in the recharge zone and the discharge zone, and they can contribute a recharge or a discharge function (Anderson and Munter, 1981). In the groundwater-recharge zone, seepage lakes differ from recharge lakes by their $\mathrm{pH}$, which is more alkaline, while in the groundwater-discharge zone, seepage lakes differ from discharge lakes by the absence of an outlet, meaning that they receive less input than discharge lakes (Fig. 8). Lakewater chemistry and the presence of outlets have been used in several studies as a classification criterion (e.g. Ala-aho et al., 2013; Winter, 1977; Newton and Driscoll, 1990). NMDS (Fig. 6b) and Wilcoxon signed-rank test (Table A3) analysis showed that all conservative and non-conservative tracers are statistically different between the three types of lakes, except for $\mathrm{SO}_{4}$. Groundwater-discharge lakes and groundwaterrecharge lakes are distinctly separated in ordination space, confirming the importance of elevation in controlling lakewater geochemistry. At the same time, seepage lakes overlap with groundwater-discharge lakes, implying that both types share similarities as they are groundwater-dependent lakes and that the three types of lakes constitute a continuum based on groundwater connectedness. The existence of a larger polygon for seepage lakes and mostly for groundwaterdischarge lakes is likely the result of greater water geochemistry heterogeneity as increased groundwater connectedness is associated with more interactions with different types of groundwater flow (Tóth, 1963).

As noted earlier, lakes can first be classified according to their location within the groundwater system, particularly above and below the hydraulic midline (i.e. the boundary between the groundwater-recharge and discharge areas) at or near the $282 \mathrm{~m}$ a.s.l. elevation in this study, which indicated a break point in the many isotopic and limnological variables (282 $\mathrm{m}$ a.s.l.) associated with differences in hydrological in- 


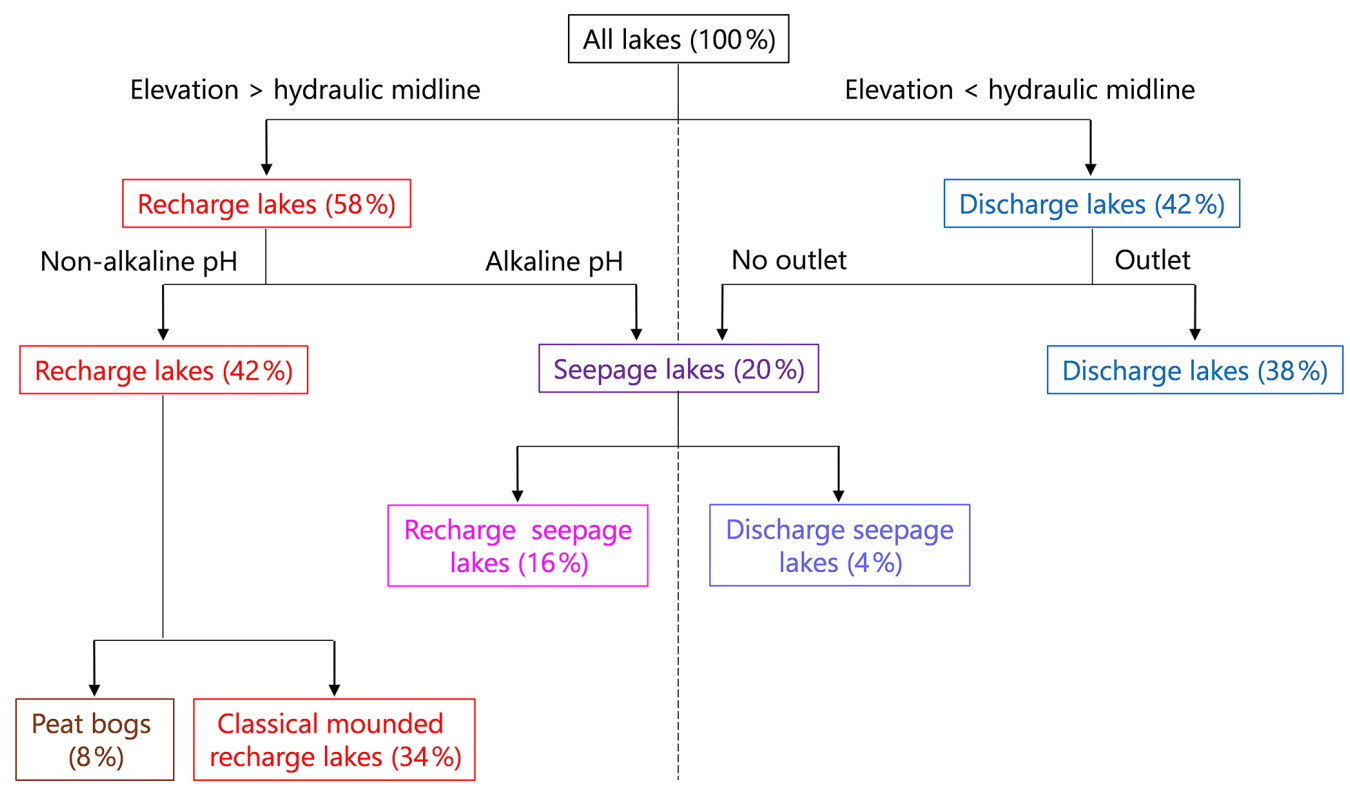

Figure 7. Illustration of a novel lake typology for the study lakes. Lake elevation was used as the primary factor in separating lakes, with elevation being an effective surrogate for dividing lakes based on the contribution of groundwater flow to a lake. The lakes were then separated based on the presence of an outlet as well as lake-water $\mathrm{pH}$ and other morphological characteristics of the lakes.

puts. In this study, elevation appears to be a proxy of the boundary between the groundwater-recharge and discharge zones on the esker. Seepage lakes, however, can be found on each side of the hydraulic midline, thus generating additional classes of lakes (see conceptual diagram; Fig. 7) distinguished by the presence or absence of a lake outlet (Fig. A1; Stauffer and Wittchen, 1992). Lakes with outlets were classified as "groundwater-discharge lakes" and lakes without outlets as "discharge seepage lakes".

Lakes with outlets are typically found at the contact between the impermeable glaciolacustrine clay plain and the permeable glaciofluvial esker sand contact where groundwater springs emerge (Fig. 1b). Furthermore, in the study area, there is a significant relation between elevation and the maximum lake perimeter slope $(r=0.75, n=50$ and $p<0.001)$. Surficial geology is also a variable used as a classification criterion in several studies (Winter, 1977; Martin et al., 2011). Lakes located at the edge of the esker tend to have steeper perimeter slopes and have low elevations, which increases the likelihood of lakes being in contact with deeper groundwater flows (Winter, 1976). These lakes receive a substantial inflow of groundwater due to their geological setting, and their water isotopic and chemical composition is similar to the one of groundwater springs and outlets (Ala-aho et al., 2013).

Only two lakes in the groundwater-discharge zone are without outlets and are classified as discharge seepage lakes. The following hypothesis could potentially explain the absence of outlet: the ability of the lakes to lose water to groundwater or a reduced input from groundwater or sur- face inflow. Yet some lakes with outlets, like Pit Lake, can be found at elevations corresponding to the groundwaterrecharge zone (Fig. 5). The presence of Pit Lake at a distinctly high elevation ( $296 \mathrm{~m}$ a.s.l.) is nonetheless explained by the location of this lake at the clay-sand interface (Fig. 1b). This suggests that elevation is just a putative variable or, in other words, a proxy of the actual hydraulic midline delineated by the clay-sand interface. This is confirmed numerically by applying a logistic regression to the presence or absence of a lake outlet and lake elevation, which provided a poor relation (Mc-Fadden $r=0.40, n=50$ and $p<0.01$ ). On the other hand, the logistic regression of the presence or absence of a lake outlet to the closest distance to the sandclay contact provided a better relation (Mc-Fadden $r=0.69$, $n=50$ and $p<0.001$ ), although it is challenging to find the real clay-sand interface, as the lateral sands can mask the real exact location (Fig. 1b) and surficial geological maps have errors in tens of metres in comparison to field observations.

Some lakes in the recharge zone, called "recharge seepage lakes", have an alkaline or a circumneutral $\mathrm{pH}$ and higher solute content, signifying that they interact to some extent with groundwater. This could occur for a number of reasons related to the existence of significant groundwater input, including (i) slightly steeper lake watershed slopes, (ii) geographical proximity to the clay-sand interface, (iii) lake relative deepness allowing interactions with deeper groundwater flows or a combination of those.

Recharge lakes can be further subdivided into two types of recharge lakes: "classical" recharge lakes and peat bogs (Fig. 7), adding a fifth type of lake to the typology (Newton 
and Driscoll, 1990). Sampled peat bogs are very small and shallow lakes, rimmed by floating mats of vegetation (typically less than 1 ha and 1 to $2 \mathrm{~m}$ deep), are acidic and are characterized by a very low amount of solutes (maximum $30 \mu \mathrm{S} \mathrm{cm}^{-1}$ ), a relatively high amount of dissolved organic carbon (above $10 \mathrm{ppm}$ ) and water isotopic composition controlled by short-term hydroclimatic conditions (enriched in heavy water isotopes during drier periods and similar to the isotopic composition of precipitation during wet periods). This could result from relative hydrological isolation from the groundwater system due to the thick layer of peat at the bottom of the lakes, formed by the successive accumulation of sedge and sphagnum characterized by a low hydraulic conductivity (Newton and Driscoll, 1990). As a consequence, direct precipitation would be the predominant source of water, making these lakes sensitive to hydroclimatic variability.

A sixth type of lake can be added to the proposed lake typology: ephemeral kettle ponds, commonly called dry kettles, even though they are not lakes per se. They can be identified in geological maps, aerial photography and satellite imagery. Dry kettles consist of small kettle holes adjacent to the esker crest that are usually but not always too high in elevation and shallow to be connected to the water table and will be dry during the summer months and most of the year, creating patches of bare land or wetlands in the forested landscape.

Based on this typology, $42 \%$ of the sampled lakes were recharge lakes, $20 \%$ seepage lakes and $38 \%$ discharge lakes. Other studies report slightly different proportions (e.g. Anderson and Munter, 1981), as might be expected based on the geographical location, the size of the study area and other factors relative to the groundwater system. The subdivision of lakes into recharge and discharge lakes is consistent with Ala-aho et al. (2013), who worked in similar settings and established their classification based on water solutes. The threefold typology compares well with Turner et al. (2010), who also established a three-category lake typology, although the terminology of the three lake types differs and $E / I$ and $f$ values were used as the primary classification criteria. Hence, the threefold typology of Fig. 7 is particularly relevant for water resources management in esker complexes, as it uses readily available variables (i.e. elevation, specific conductance and $\mathrm{pH}$, and presence and/or absence of an outlet).

Discharge (groundwater discharge) lakes have the highest $\mathrm{pH}$, and amounts of solutes, while the opposite is observed for recharge lakes. Seepage lakes have intermediate values compared to the other two lake types. The same patterns are observed for isotopic values: recharge lakes tend to be enriched in heavier water isotopes, discharge lakes tend to be depleted in heavier isotopes, and seepage lakes are characterized by intermediate values. This reinforces the interpretation that seepage lakes are a hybrid type between recharge and discharge lakes. Seepage lakes thus tend to be closer to recharge lakes on an isotopic basis but more similar to discharge lakes on a chemical basis. This is explained by the fact that most sampled seepage lakes are located in the recharge zone, and those receive some intermediate groundwater flows.

Recharge lakes contain higher amounts of dissolved organic matter likely due to substantial water-residence times, whereas seepage lakes and discharge lakes can have sustained inflow of groundwater that decreases water-residence times. The concentration of DOC in discharge lakes is relatively higher than expected, as groundwater usually contains limited organic matter. This is likely an artefact of lake morphology and anthropogenic activities. Indeed, values of DOC for discharge lakes display a high standard deviation due to a subgroup of smaller lakes that are relatively deep and without cottages combined with another group of larger lakes that are relatively shallow with the presence of cottages. Relatively shallow lakes are known to have significantly higher amounts of DOC than deeper ones as a result of smaller volumes relative to inputs, and potential reworking of bottom organic matter and nutrients due to the shallow water columns. DOC values for discharge lakes also contain two sizable outliers that skew the average and median: Night Hawk Lake and Frederick House Lake, both of which are regional highorder and large lakes (10701 and 3888 ha respectively) that are relatively shallow (maximum depth of 4.6 and $12.0 \mathrm{~m}$ respectively) and are heavily used for recreational purposes.

\subsection{Lake morphometry and water geochemistry}

There are additional morphometric factors that influence lake-water isotopic composition in these settings. Evaporation over a water body is enhanced when there is a strong gradient of temperature and water vapour pressure between the lake water and the adjacent air. Assuming that there are no large microclimate differences within the esker complex, isotopic values may be influenced by (i) the lake fetch $(r=-0.26, n=48$ and $p=0.07)$, as wind is more efficient at removing moisture over a long distance (Granger and Hedstrom, 2011), (ii) relative depth $(r=-0.32, n=32$ and $p=0.07$ ), as lakes that have a large surface compared to their depth are proportionally more exposed to the atmosphere and thus more susceptible to evaporation, and (iii) the steepness of the slopes surrounding the lake $(r=-0.33$, $n=48$ and $p=0.02$ ). Among those variables, only the last variable is significantly related to the isotopic composition of the lake, while the other two may be marginally significant. Steep slopes tend to reduce evaporation rates by blocking air flows over the lake, thus reducing wind speed, water-air temperature and water vapour pressure contrasts, and to increase the likelihood of lakes to be in contact with deeper groundwater flows (Winter, 1976).

Lake-water chemistry can also be influenced by lake morphometry. Lake depth has been known to play a role (Winter, 1976). It seems that a priori there is no relation between lake maximum depth and specific conductance $(r=0.09, n=39$ 
and $p=0.59)$. However, to determine whether the relation between specific conductance and lake maximum depth varied with lake landscape position, two separate regressions analyses were carried out for recharge $(r=0.01, n=16$ and $p=0.66)$ and discharge lakes $(r=0.30, n=23$ and $p=0.05)$. The two regressions show that maximum depth can act as a control on specific conductance only in lakes in the discharge zone: the deeper the lake, the deeper soluterich groundwater flows seep into the lake. It is also expected that small lakes with a large ratio of perimeter to surface area $(r=0.48, n=48$ and $p<0.001)$ will have a higher amounts of solutes, as the majority of groundwater seepage into the lake is typically localized near the shoreline (Rosenberry et al., 2015).

Water-quality tracers (DOC and $\mathrm{TN}$ ) were not correlated to elevation, suggesting that there is no relationship between groundwater inflow and water quality. But the correlation between water-quality tracers and the ratio of lake perimeter to surface area may suggest a relation between lake morphometry and water quality. Elongated lakes have a proportionally greater interface with terrestrial ecosystem, which favours the inflow of nutrients in lakes, while mean depth is seen as an indicator of water-residence times and rates of mixing (Mulholland, 2003; Knoll et al., 2015).

Given that some lacustrine morphometric variables are correlated to some water tracers, it can be argued that lake morphometry can play a significant role on lake-water biogeochemistry and introduce some complexity in the lake typology. In fact, some lake typologies incorporate morphometric features as defining characteristics (e.g. Winter, 1977; Martin et al., 2011; Knoll et al., 2015). Even though water tracers show a stronger correlation with elevation than with morphometric features, it cannot be assessed with certainty that elevation accounts for much more variance in isotopic composition and specific conductance, as certain other key morphometric variables are not available for comparison. Such variables include the lake network number or the measure of connections to other lakes, which can modify lake isotopic composition or the lake-to-catchment-area ratio, which can affect lake-water chemistry. In other studies, land use has been identified as a key variable explaining lake-water balance (as canopy cover reduces evaporative losses) and water chemistry (as substrate and water pathways influence water chemistry; e.g. Turner et al., 2010, 2014a, b). However, given the predominance of the boreal forest in the study area, the impact of land use on water geochemistry was not considered to be an explanatory variable. Specific yield and soil type are additional variables that can also impact lake isotopic composition and lake-water chemistry. Hence, several morphometric and geophysical variables can modify lake chemistry and make the relation between elevation and lake-water balance and/or water chemistry more complex.

\subsection{Implications for water balance, hydrochemistry and response to external stressors}

Results from the study show that the water balance of individual lakes is highly dependent on the nature of their interactions with the groundwater system, which is in turn determined by landscape position at highly localized scale, as shown in the conceptual model in Fig. 8a. Under drier hydroclimatic conditions, groundwater-discharge lakes undergo minimal to negative changes in water balance, as the continuous flow of isotopically light groundwater masks evaporative enrichment, whereas groundwater-recharge lakes are highly sensitive to evaporation because they rely on precipitation as their primary source of water. Seepage lakes constitute a hybrid between recharge and discharge, and their water balance is between the other two lake types (Fig. 4b). These patterns of change were observed when comparing changes in $E / I$ and $f$ ratios between sampling campaigns: $E / I$ and $f$ ratios experienced negative noticeable changes in groundwater-discharge lakes and small changes in seepage lakes, while positive changes in $E / I$ and $f$ were observed in groundwater-recharge lakes (Fig. $8 \mathrm{~b}$ and c). Consequently, upland groundwater-recharge lakes will be more prone to evaporative drawdown and therefore more sensitive to short-term climate change and droughts, while groundwater-discharge lakes will be buffered by groundwater inflow and affected by hydroclimatological changes of greater duration and persistence that alter water table position (Fig. 8a). Seepage lakes will presumably be sensitive to drought, but not to the same extent as groundwater-recharge lakes since they have stronger interactions with groundwater (Fig. 8a). This suggests that the esker hydrological system can respond to a large-scale hydroclimatic forcing (e.g. prolonged drought) in a manner that affects individual lakes differently. The degree of interaction with groundwater by an individual lake will also dictate the response to strong hydroclimatic forcings and introduce time lags (Webster et al., 2000).

Similarly, the water-chemistry gradient between upland solute-poor lakes and lowland solute-rich lakes could make recharge lakes more vulnerable to acidification than seepage and discharge lakes. The effects of changing hydroclimatic conditions on lake-water chemistry across the landscape observed during successive sampling in June 2013, June 2014 and August 2014 resulted in a heterogeneous pattern depending on the lake type, consistent with the findings of Webster et al. (1996). Groundwater-recharge lakes did not respond chemically to short-term hydroclimatic change, as they feed the groundwater system by lake out-seepage, thus producing no net change in solutes, while seepage and groundwaterdischarge lakes displayed significant solute changes (Fig. 8b and c). Based on the limited sampling frequency, it is difficult to draw conclusions on the seepage or discharge lake types that undergo the most chemical variation. A greater temporal resolution of sampling would provide more in- 


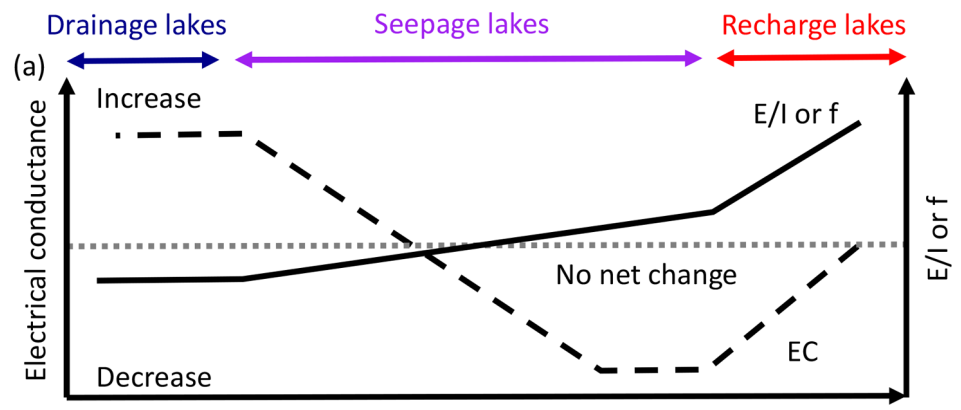

Groundwater interaction
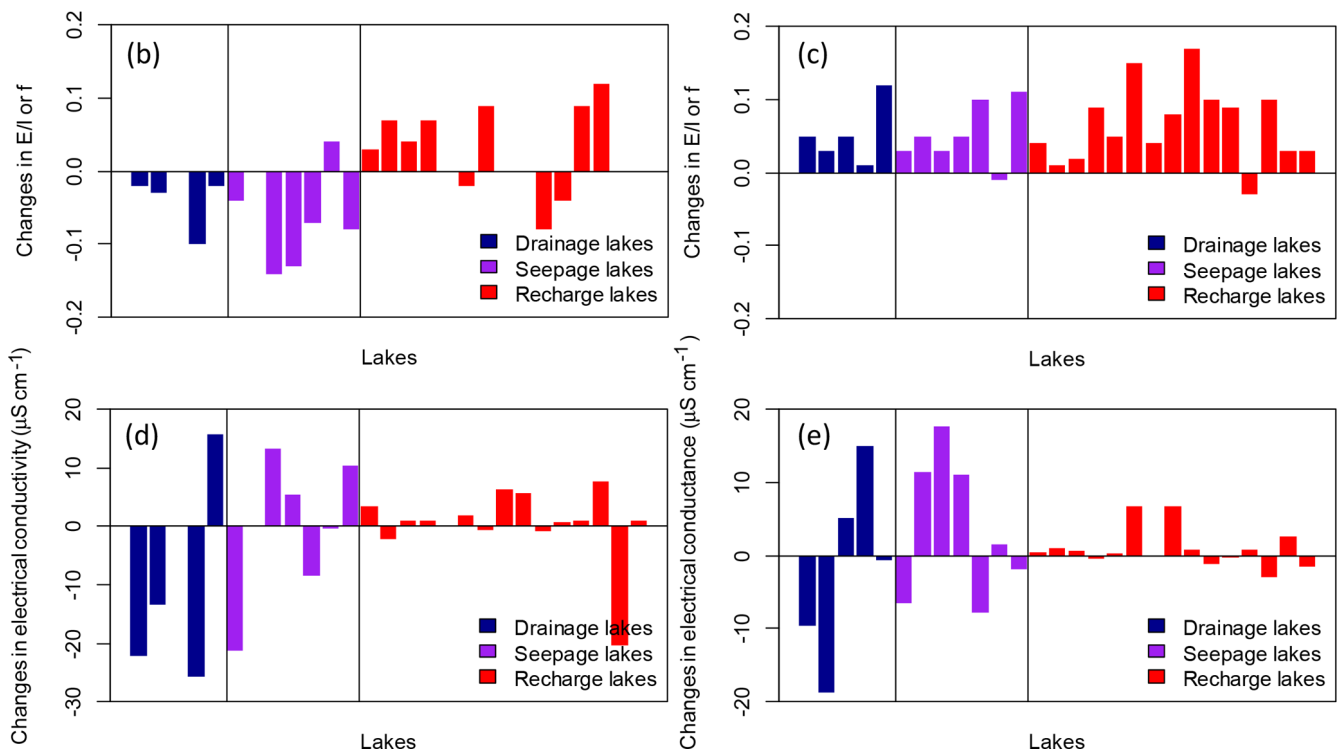

Figure 8. Conceptual model of the relationship between the direction and magnitude of lake $E / I$ or $f$ and EC changes during drier conditions according to lake type, defined by the degree to which lakes interact with groundwater (modified from Webster et al., 1996) (a). Observed changes in $E / I$ or $f$ between June 2013 and June 2014 (E/I 2014-E/I 2013) (b), changes in $E / I$ between August 2014 and June 2014 ( $E / I$ or $f$ August to $E / I$ or $f$ June) (c), changes in specific conductance between June 2013 and June 2014 (EC 2014-EC 2013) (d), and changes in electrical conductance between August and June 2014 (EC August-EC June) (e) by lake type.

sights into short-term changes in hydrochemistry in relation to short-term hydroclimatic fluctuations and reinforce these interpretations. However, Webster et al. (1996) suggest that groundwater-discharge lakes and seepage lakes respond chemically to evaporative drawdown in opposite ways, with seepage lakes showing a decline in solutes during droughts as inputs from groundwater diminish due to the lowering of the water table (Fig. 8a). By contrast, groundwater-discharge lakes have been noted as being susceptible to evaporative enrichment of solutes and increased relative contribution of solute-rich groundwater during drought periods (Kratz et al., 1997). For these reasons, Webster et al. (1996) suggested that climate change could amplify anthropogenic impacts and make lakes more vulnerable to other stressors, such as lake acidification.

Due to their varied hydrological characteristics, the lake types identified in this study will have a different susceptibilities to direct anthropogenic impacts. Because groundwaterrecharge lakes have lower groundwater inflow, they are char- acterized by relatively long water-residence times, making them highly vulnerable to inputs and pollutants in comparison to seepage lakes and groundwater-discharge lakes that tend to have a greater watershed, which results in increased flushing. Given this situation, the limitation of cottage development and disposal sites in the groundwater-recharge zone and/or stricter regulations on cottage septic tanks in this zone would prevent the downstream contamination and subsequent degradation of water quality in the groundwaterdischarge zone delimited in Fig. 5. However, it can be argued that differences in material permeability between the esker and the clay plain can produce the opposite effect, as clays and organic deposits on the esker flanks act as an aquitard that locally confines the aquifer (Fig. 1b; Rossi et al., 2012). Sand extraction and mining activities in the groundwaterdischarge zone could potentially influence the water levels of upland lakes in the recharge zone (Kløve et al., 2011). Indeed, material excavation and tunnel construction can cause the desiccation of groundwater-dependent systems by revers- 
ing flow patterns in the recharge area and increase the discharge from the esker along the esker flanks after ditching and drain groundwater-dependent systems in the recharge area (Kløve et al., 2011; Rossi et al., 2012). As a result, the implementation of incidence studies that investigate and take into account local groundwater flow patterns and hydrological connections between the recharge and discharge areas prior to any excavation project in those settings would allow the assessment of any undesired effects on hydrological systems and their functions and services. This potential was acknowledged by an impact study undertaken for an aborted aggregate pit project in the study area, and one recommendation was the construction of an engineered frozen earth barrier to prevent groundwater flow into the proposed pit in order to minimize the effects on the water table and surrounding lake levels (Cochrane, 2006).

Finally, when considering groundwater-fed lakes for the purposes of paleohydrological reconstruction (e.g. Laird et al., 2012), it is critical to explore their modern hydrology to be able to have a baseline for comparison to future hydrological regimes that may alter them. Knowledge of the modern lake hydrology is also needed to correctly interpret the probable causes of isotopic, chemical and biological change and variability recorded in the sediment through time along with their potential hydroclimatic drivers. Because the degree to which lakes interact with groundwater produces differences in hydrologic response to the same hydroclimatic forcing, the interpretation of paleolimnological records can be complex (Fritz et al., 2000), and multiple site selection seems necessary, as a groundwater-discharge lake may show long-term stability while a groundwater-recharge lake may display significant short-term and long-term variability (Bennett et al., 2007).

\section{Conclusions}

Lakes located in an esker complex in northeastern Ontario showed strong systematic and localized differences in terms of water balance and hydrochemistry, similar to other esker complexes in other settings. Results from this study indicated that elevation is a critical factor explaining water chemistry and water balance across the landscape. As eskers are structurally complex and often characterized by high hydraulic conductivity, groundwater interactions are an important component of lake-water hydrology. Low-elevation lakes are likely interconnected with solute-rich intermediate and regional groundwater flow paths while upland lakes are only interacting with local solute-poor groundwater flow paths. This threshold in water chemistry is also accompanied by strong contrasts in lake-water balance. Upland lakes tend to be isotopically enriched and more sensitive to evaporation, while lowland lakes are more depleted and subject to groundwater inflows. Limnological variables including lake depth, DOC and forms of nitrogen were weakly related to el- evation and likely influenced by lake morphometry and watershed activities. Thus, these results are in agreement with other studies that indicate that at the local scale, landscape position is the main control on lake-water chemistry and balance, while lake morphometric characteristics explain additional variance.

The physical and chemical characteristics of lake water allowed the development of a lake typology that is made of three main types of lakes: (i) higher-elevation groundwater-recharge lakes, essentially fed by precipitation, which are characterized by higher evaporations rates and lower amounts of solutes, (ii) seepage lakes that both gain and lose water to the groundwater, which are characterized by intermediate rates of evaporation and amounts of solutes, and (iii) lower-elevation groundwater-discharge lakes, which are continuously fed by groundwater inflow and characterized by almost no evaporation rates and higher amounts of solutes. The obtained typology provides insights into lake vulnerability to environmental stressors, particularly short- and long-term hydroclimatic change. Groundwaterrecharge lakes will be more prone to evaporative drawdown and therefore more sensitive to short-term droughts, while groundwater-discharge lakes will be buffered by groundwater inflow and affected by hydroclimatological changes of greater persistence. Similarly, recharge lakes will likely be more subject to other anthropogenic impacts in comparison to groundwater-discharge lakes. 


\section{Appendix A}

Table A1. Correlation matrix between hydrological tracers and morphometric variables.

\begin{tabular}{|c|c|c|c|c|c|c|c|c|c|c|c|c|c|}
\hline (a) & $\mathrm{EC}$ & $\mathrm{pH}$ & $T$ & $\mathrm{Ca}^{2+}$ & $\mathrm{Mg}^{2+}$ & $\mathrm{K}^{+}$ & $\mathrm{Na}^{+}$ & $\mathrm{Cl}^{-}$ & $\mathrm{SO}_{4}^{2-}$ & $\mathrm{NO}_{3}^{-}$ & $\mathrm{NH}_{4}^{+}$ & $\delta^{18} \mathrm{O}$ & $\delta^{2} \mathrm{H}$ \\
\hline EC & 1.00 & 0.73 & -0.22 & 0.97 & 0.93 & 0.73 & 0.60 & 0.62 & 0.36 & -0.13 & -0.18 & -0.80 & -0.75 \\
\hline $\mathrm{pH}$ & 0.73 & 1.00 & -0.05 & 0.76 & 0.73 & 0.41 & 0.29 & 0.29 & 0.20 & -0.15 & -0.18 & -0.47 & -0.41 \\
\hline$T$ & -0.22 & -0.05 & 1.00 & -0.24 & -0.25 & -0.32 & 0.06 & 0.05 & -0.12 & 0.19 & -0.16 & 0.34 & 0.33 \\
\hline $\mathrm{Ca}^{2+}$ & 0.97 & 0.76 & -0.24 & 1.00 & 0.94 & 0.66 & 0.43 & 0.48 & 0.40 & -0.12 & -0.18 & -0.83 & -0.78 \\
\hline $\mathrm{Mg}^{2+}$ & 0.93 & 0.73 & -0.25 & 0.94 & 1.00 & 0.72 & 0.36 & 0.37 & 0.26 & -0.12 & -0.18 & -0.77 & -0.73 \\
\hline $\mathrm{K}^{+}$ & 0.73 & 0.41 & -0.32 & 0.66 & 0.72 & 1.00 & 0.56 & 0.49 & 0.37 & -0.01 & 0.05 & -0.55 & -0.51 \\
\hline $\mathrm{Na}^{+}$ & 0.60 & 0.29 & 0.06 & 0.43 & 0.36 & 0.56 & 1.00 & 0.95 & 0.12 & -0.06 & -0.07 & -0.31 & -0.29 \\
\hline $\mathrm{Cl}^{-}$ & 0.62 & 0.29 & 0.05 & 0.48 & 0.37 & 0.49 & 0.95 & 1.00 & 0.06 & -0.06 & -0.04 & -0.35 & -0.33 \\
\hline $\mathrm{SO}_{4}^{2-}$ & 0.36 & 0.20 & -0.12 & 0.40 & 0.26 & 0.37 & 0.12 & 0.06 & 1.00 & 0.03 & -0.05 & -0.33 & -0.30 \\
\hline $\mathrm{NO}_{3}^{-}$ & -0.13 & -0.15 & 0.19 & -0.12 & -0.12 & -0.01 & -0.06 & -0.06 & 0.03 & 1.00 & 0.04 & 0.16 & 0.16 \\
\hline $\mathrm{NH}_{4}^{+}$ & -0.18 & -0.18 & -0.16 & -0.18 & -0.18 & 0.05 & -0.07 & -0.04 & -0.05 & 0.04 & 1.00 & 0.14 & 0.16 \\
\hline$\delta^{18} \mathrm{O}$ & -0.80 & -0.47 & 0.34 & -0.83 & -0.77 & -0.55 & -0.31 & -0.35 & -0.33 & 0.16 & 0.14 & 1.00 & 0.99 \\
\hline$\delta^{2} \mathrm{H}$ & -0.75 & -0.41 & 0.33 & -0.78 & -0.73 & -0.51 & -0.29 & -0.33 & -0.30 & 0.16 & 0.16 & 0.99 & 1.00 \\
\hline$d$ & 0.84 & 0.53 & -0.34 & 0.87 & 0.82 & 0.59 & 0.33 & 0.37 & 0.35 & -0.16 & -0.11 & -0.99 & -0.96 \\
\hline$E / I f$ & -0.80 & -0.66 & 0.45 & -0.83 & -0.77 & -0.59 & -0.37 & -0.30 & -0.78 & 0.18 & 0.24 & 0.94 & 0.93 \\
\hline $\mathrm{TC}$ & 0.96 & 0.75 & -0.43 & 0.96 & 0.95 & 0.74 & 0.59 & 0.42 & 0.36 & -0.17 & -0.03 & -0.88 & -0.85 \\
\hline DOC & -0.12 & -0.25 & -0.05 & -0.09 & -0.19 & 0.26 & 0.00 & -0.14 & 0.59 & -0.03 & 0.50 & -0.06 & -0.08 \\
\hline DIC & 0.96 & 0.81 & -0.38 & 0.95 & 0.97 & 0.62 & 0.56 & 0.44 & 0.16 & -0.16 & -0.21 & -0.82 & -0.79 \\
\hline TN & -0.22 & -0.30 & -0.09 & -0.21 & -0.29 & 0.16 & 0.00 & -0.09 & 0.44 & -0.06 & 0.53 & 0.08 & 0.06 \\
\hline $\mathrm{C} / \mathrm{N}$ & -0.13 & -0.21 & 0.28 & -0.10 & -0.10 & 0.12 & -0.10 & -0.20 & 0.35 & 0.04 & 0.17 & -0.07 & -0.08 \\
\hline$H$ & -0.67 & -0.57 & 0.04 & -0.69 & -0.72 & -0.55 & -0.31 & -0.28 & -0.25 & 0.08 & 0.16 & 0.53 & 0.49 \\
\hline$Z$ & 0.09 & 0.20 & 0.17 & 0.06 & 0.18 & 0.06 & -0.01 & 0.00 & -0.18 & 0.08 & 0.01 & 0.01 & 0.05 \\
\hline$S$ & 0.51 & 0.50 & -0.04 & 0.52 & 0.53 & 0.45 & 0.22 & 0.16 & 0.39 & -0.10 & -0.24 & -0.33 & -0.27 \\
\hline A & 0.35 & 0.40 & 0.23 & 0.37 & 0.38 & 0.32 & 0.20 & 0.17 & 0.18 & -0.06 & -0.08 & -0.24 & -0.21 \\
\hline$P$ & 0.42 & 0.53 & 0.25 & 0.45 & 0.45 & 0.35 & 0.21 & 0.17 & 0.24 & -0.07 & -0.13 & -0.29 & -0.27 \\
\hline$P / A$ & -0.48 & -0.73 & -0.28 & -0.48 & -0.49 & -0.29 & -0.29 & -0.23 & -0.40 & 0.00 & 0.21 & 0.10 & 0.02 \\
\hline (b) & $d$ & $E / I f$ & TC & DOC & DIC & $\mathrm{TN}$ & $\mathrm{C} / \mathrm{N}$ & $H$ & $Z$ & $S$ & $A$ & $P$ & $P / A$ \\
\hline EC & 0.84 & -0.80 & 0.96 & -0.1 & 0 . & -0.22 & -0.13 & -0 & 0.09 & 0.51 & 0 & 0.42 & -0.48 \\
\hline $\mathrm{pH}$ & 0.53 & -0.66 & 0.75 & -0.25 & 0.81 & -0.30 & -0.21 & -0.57 & 0.20 & 0.50 & 0.4 & 0.53 & -0.73 \\
\hline$T$ & -0.34 & 0.45 & -0.43 & -0.05 & -0.38 & -0.09 & 0.28 & 0.04 & 0.17 & -0.04 & 0.23 & 0.25 & -0.28 \\
\hline $\mathrm{Ca}^{2+}$ & 0.87 & -0.83 & 0.96 & -0.09 & 0.95 & -0.21 & -0.10 & -0.69 & 0.06 & 0.52 & 0.37 & 0.45 & -0.48 \\
\hline $\mathrm{Mg}^{2+}$ & 0.82 & -0.77 & 0.95 & -0.19 & 0.97 & -0.29 & -0.10 & -0.72 & 0.18 & 0.53 & 0.38 & 0.45 & -0.49 \\
\hline $\mathrm{K}^{+}$ & 0.59 & -0.59 & 0.74 & 0.26 & 0.62 & 0.16 & 0.12 & -0.55 & 0.06 & 0.45 & 0.32 & 0.35 & -0.29 \\
\hline $\mathrm{Na}^{+}$ & 0.33 & -0.37 & 0.59 & 0.00 & 0.56 & 0.00 & -0.10 & -0.31 & -0.01 & 0.22 & 0.20 & 0.21 & -0.29 \\
\hline $\mathrm{Cl}^{-}$ & 0.37 & -0.30 & 0.42 & -0.14 & 0.44 & -0.09 & -0.20 & -0.28 & 0.00 & 0.16 & 0.17 & 0.17 & -0.23 \\
\hline $\mathrm{SO}_{4}^{2-}$ & 0.35 & -0.75 & 0.36 & 0.59 & 0.16 & 0.44 & 0.35 & -0.25 & -0.18 & 0.39 & 0.18 & 0.24 & -0.40 \\
\hline $\mathrm{NO}_{3}^{-}$ & -0.16 & 0.18 & -0.17 & -0.03 & -0.16 & -0.06 & 0.04 & 0.08 & 0.08 & -0.10 & -0.06 & -0.07 & 0.00 \\
\hline $\mathrm{NH}_{4}^{+}$ & -0.11 & -0.24 & -0.03 & 0.50 & -0.21 & 0.53 & 0.17 & 0.16 & 0.01 & -0.24 & -0.08 & -0.13 & 0.21 \\
\hline$\delta^{18} \mathrm{O}$ & -0.99 & 0.94 & -0.88 & -0.06 & -0.82 & 0.08 & -0.07 & 0.53 & 0.01 & -0.33 & -0.24 & -0.29 & 0.10 \\
\hline$\delta^{2} \mathrm{H}$ & -0.96 & 0.93 & -0.85 & -0.08 & -0.79 & 0.06 & -0.08 & 0.49 & 0.05 & -0.27 & -0.21 & -0.27 & 0.02 \\
\hline$d$ & 1.00 & -0.92 & 0.90 & 0.05 & 0.85 & -0.11 & 0.05 & -0.57 & 0.04 & 0.40 & 0.28 & 0.32 & -0.20 \\
\hline$E / I f$ & -0.92 & 1.00 & -0.81 & 0.37 & -0.81 & 0.49 & -0.05 & 0.48 & -0.07 & -0.37 & -0.22 & -0.31 & 0.24 \\
\hline $\mathrm{TC}$ & 0.90 & -0.81 & 1.00 & 0.05 & 0.94 & -0.05 & 0.01 & -0.64 & 0.03 & 0.50 & 0.31 & 0.38 & -0.27 \\
\hline DOC & 0.05 & 0.37 & 0.05 & 1.00 & -0.29 & 0.93 & 0.66 & -0.04 & -0.29 & 0.08 & 0.00 & -0.12 & 0.54 \\
\hline DIC & 0.85 & -0.81 & 0.94 & -0.29 & 1.00 & -0.37 & -0.21 & -0.60 & 0.12 & 0.45 & 0.29 & 0.39 & -0.40 \\
\hline $\mathrm{TN}$ & -0.11 & 0.49 & -0.05 & 0.93 & -0.37 & 1.00 & 0.40 & 0.05 & -0.43 & -0.03 & -0.01 & -0.10 & 0.60 \\
\hline $\mathrm{C} / \mathrm{N}$ & 0.05 & -0.05 & 0.01 & 0.66 & -0.21 & 0.40 & 1.00 & -0.09 & 0.08 & 0.18 & 0.07 & -0.03 & 0.03 \\
\hline$H$ & -0.57 & 0.48 & -0.64 & -0.04 & -0.60 & 0.05 & -0.09 & 1.00 & -0.26 & -0.77 & -0.46 & -0.50 & 0.53 \\
\hline Z & 0.04 & -0.07 & 0.03 & -0.29 & 0.12 & -0.43 & 0.08 & -0.26 & 1.00 & 0.30 & -0.02 & 0.04 & -0.40 \\
\hline$S$ & 0.40 & -0.37 & 0.50 & 0.08 & 0.45 & -0.03 & 0.18 & -0.77 & 0.30 & 1.00 & 0.33 & 0.35 & -0.52 \\
\hline A & 0.28 & -0.22 & 0.31 & 0.00 & 0.29 & -0.01 & 0.07 & -0.46 & -0.02 & 0.33 & 1.00 & 0.91 & -0.49 \\
\hline$P$ & 0.32 & -0.31 & 0.38 & -0.12 & 0.39 & -0.10 & -0.03 & -0.50 & 0.04 & 0.35 & 0.91 & 1.00 & -0.55 \\
\hline$P / A$ & -0.20 & 0.24 & -0.27 & 0.54 & -0.40 & 0.60 & 0.03 & 0.53 & -0.40 & -0.52 & -0.49 & -0.55 & 1.00 \\
\hline
\end{tabular}

Note: electrical conductance (EC) is expressed in $\mu \mathrm{Scm}^{-1}$; temperature $(T)$ in ${ }^{\circ} \mathrm{C}$; dissolved ions $\left(\mathrm{Ca}^{2+}, \mathrm{Mg}^{2+}, \mathrm{K}^{+}, \mathrm{Na}^{+}, \mathrm{Cl}^{-}, \mathrm{SO}_{4}^{2-}, \mathrm{NO}_{2}^{-}-\mathrm{NO}_{3}^{-}\right.$and $\left.\mathrm{NH}_{4}^{+}\right)$in parts per million; water stable isotopes $\left(\delta^{18} \mathrm{O}\right.$ and $\left.\delta^{2} \mathrm{H}\right)$ and deuterium excess $(d)$ in \%o V-SMOW; total carbon (TC), dissolved organic carbon (DOC), dissolved inorganic carbon (DIC) and total nitrogen (TN) in parts per million; elevation $(H)$, lake maximum depth $(Z)$ and perimeter $(P)$ in metres; maximum lake perimeter slope $(S)$ in percent; and area $(A)$ in hectares. 
Table A2. Results of the Wilcoxon signed-rank test of individual conservative and non-conservative hydrological tracers using the two-class lake typology as the categorical variable. Non-significant $p$ values are indicated in bold. Lakes in the recharge zone are defined as lakes above an elevation of $282 \mathrm{~m}$ a.s.l., whereas lakes in the discharge zone are defined as lakes located at an elevation of less than $282 \mathrm{~m}$ a.s.l.

\begin{tabular}{lrrrr}
\hline & Lakes in the recharge zone & Lakes in the discharge zone & Wilcoxon signed-rank test \\
\cline { 4 - 5 } Variable & mean $(\mathrm{SD})$ & mean $(\mathrm{SD})$ & $V$ value & $p$ value \\
\hline $\mathrm{EC}\left(\mu \mathrm{S} \mathrm{cm}^{-1}\right)$ & $47.6(53.5)$ & $230.4(88.4)$ & 1275 & $p<0.001$ \\
$\mathrm{pH}$ & $6.7(0.9)$ & $7.9(0.4)$ & 1275 & $p<0.001$ \\
$T\left({ }^{\circ} \mathrm{C}\right)$ & $17.0(1.9)$ & $16.5(2.6)$ & 1275 & $p<0.001$ \\
$\mathrm{Ca}^{2+}(\mathrm{ppm})$ & $4.8(6.6)$ & $29.4(10.7)$ & 2138 & $p<0.001$ \\
$\mathrm{Mg}^{2+}(\mathrm{ppm})$ & $1.1(1.4)$ & $7.1(3.1)$ & 1013 & $p<0.001$ \\
$\mathrm{~K}^{+}(\mathrm{ppm})$ & $0.4(0.2)$ & $1.0(0.4)$ & 699 & 0.559 \\
$\mathrm{Na}^{+}(\mathrm{ppm})$ & $0.8(1.9)$ & $5.3(7.9)$ & 867 & 0.027 \\
$\mathrm{Cl}^{-}(\mathrm{ppm})$ & $1.1(3.9)$ & $9.5(15.0)$ & 1572 & 0.024 \\
$\mathrm{SO}_{4}^{2-}(\mathrm{ppm})$ & $0.9(0.8)$ & $6.6(13.9)$ & 1003 & $p<0.001$ \\
$\mathrm{NO}_{2}^{-}-\mathrm{NO}{ }_{3}^{-}(\mathrm{ppb})$ & $8.3(25.0)$ & $56.5(297.6)$ & 638 & $p<0.001$ \\
$\mathrm{NH}_{4}^{+}(\mathrm{ppb})$ & $22.5(6.4)$ & $31.8(28.6)$ & 231 & $p<0.001$ \\
$\delta^{18} \mathrm{O}(\%)$ & $-8.7(1.4)$ & $-11.5(1.6)$ & 0 & $p<0.001$ \\
$\delta^{2} \mathrm{H}(\%)$ & $-78.2(7.1)$ & $-90.6(7.6)$ & 0 & $p<0.001$ \\
$d(\%)$ & $-8.5(4.5)$ & $1.7(5.5)$ & 234 & $p<0.001$ \\
$E / I$ or $f$ & $0.6(0.2)$ & $0.2(0.3)$ & 1406 & $p<0.001$ \\
$\mathrm{TC}(\mathrm{ppm})$ & $11.4(5.9)$ & $30.4(8.7)$ & 666 & $p<0.001$ \\
$\mathrm{DOC}(\mathrm{ppm})$ & $5.9(3.2)$ & $6.2(4.9)$ & 666 & $p<0.001$ \\
$\mathrm{DIC}(\mathrm{ppm})$ & $5.5(6.4)$ & $24.2(10.6)$ & 653 & $p<0.001$ \\
$\mathrm{TN}(\mathrm{ppm})$ & $0.5(0.2)$ & $0.5(0.3)$ & 217 & 0.069 \\
$\mathrm{Atomic} \mathrm{C} / \mathrm{N}$ & $13.2(3.3)$ & $13.6(4.0)$ & 666 & $p<0.001$ \\
Elevation $(\mathrm{m})$ & $287.7(4.8)$ & $275.1(2.8)$ & 1275 & $p<0.001$ \\
Maximum depth (m) & $12.4(6.2)$ & $13.2(6.7)$ & 1750 & $p<0.001$ \\
Maximum lake perimeter slope $(\%)$ & $9.8(6.9)$ & $20.5(5.7)$ & 1273 & $p<0.001$ \\
\hline
\end{tabular}


Table A3. Results of the Wilcoxon signed-rank test of conservative and non-conservative hydrological tracers using the three-class lake typology as the categorical variable. Non-significant $p$ values are indicated in bold. Lakes in the recharge zone are defined as lakes above an elevation of $282 \mathrm{~m}$ a.s.1. that are non-alkaline, and lakes in the seepage zone are defined as lakes above an elevation of $282 \mathrm{~m}$ a.s.1. that are alkaline, whereas lakes in the discharge zone are defined as lakes located at an elevation of less than $282 \mathrm{~m}$ a.s.l.

\begin{tabular}{|c|c|c|c|c|c|}
\hline \multirow[b]{2}{*}{ Variable } & \multirow{2}{*}{$\begin{array}{r}\text { Recharge lakes } \\
\text { mean }(\mathrm{SD})\end{array}$} & \multirow{2}{*}{$\begin{array}{r}\text { Seepage lakes } \\
\text { mean }(\mathrm{SD})\end{array}$} & \multirow{2}{*}{$\begin{array}{r}\text { Discharge lakes } \\
\text { mean (SD) }\end{array}$} & \multicolumn{2}{|c|}{ Wilcoxon signed-rank test } \\
\hline & & & & $V$ value & $p$ value \\
\hline $\mathrm{EC}\left(\mu \mathrm{Scm}^{-1}\right)$ & $20.5(11.9)$ & $135.9(60.8)$ & $233.2(92.5)$ & 1275 & $p<0.001$ \\
\hline $\mathrm{pH}$ & $6.2(0.7)$ & $7.8(0.3)$ & $7.9(0.4)$ & 1275 & $p<0.001$ \\
\hline$T\left({ }^{\circ} \mathrm{C}\right)$ & $17.1(2.0)$ & $16.4(1.7)$ & $16.5(2.8)$ & 1275 & $p<0.001$ \\
\hline $\mathrm{Ca}^{2+}(\mathrm{ppm})$ & $1.4(1.4)$ & $16.8(8.6)$ & $29.5(11.2)$ & 1705 & $p=0.002$ \\
\hline $\mathrm{Mg}^{2+}(\mathrm{ppm})$ & $0.4(0.3)$ & $3.5(1.7)$ & $7.2(3.3)$ & 927 & 0.005 \\
\hline $\mathrm{K}^{+}(\mathrm{ppm})$ & $0.5(0.3)$ & $0.4(0.1)$ & $1.0(0.4)$ & 3 & $p<0.001$ \\
\hline $\mathrm{Na}^{+}(\mathrm{ppm})$ & $0.4(0.7)$ & $1.9(2.9)$ & $5.6(8.3)$ & 876 & 0.009 \\
\hline $\mathrm{Cl}^{-}(\mathrm{ppm})$ & $0.4(1.3)$ & $3.3(6.5)$ & $9.9(15.7)$ & 832 & 0.004 \\
\hline $\mathrm{SO}_{4}^{2-}(\mathrm{ppm})$ & $0.7(0.6)$ & $1.7(1.1)$ & $7.0(14.6)$ & 486 & 0.145 \\
\hline $\mathrm{NO}_{2}^{-}-\mathrm{NO}_{3}^{-}(\mathrm{ppb})$ & $78.0(347.3)$ & $0.0(0.0)$ & $8.8(25.6)$ & 1 & $p<0.001$ \\
\hline $\mathrm{NH}_{4}^{+}(\mathrm{ppb})$ & $33.9(32.9)$ & $25.4(0.0)$ & $22.6(6.5)$ & 0 & $p<0.001$ \\
\hline$\delta^{18} \mathrm{O}(\% \circ)$ & $-8.5(1.3)$ & $-9.7(1.6)$ & $-11.6(1.7)$ & 0 & $p<0.001$ \\
\hline$\delta^{2} \mathrm{H}(\% \circ)$ & $-77.4(6.8)$ & $-82.1(7.8)$ & $-90.8(8.0)$ & 0 & $p<0.001$ \\
\hline$d(\%)$ & $-9.6(3.7)$ & $-4.5(5.4)$ & $1.9(5.7)$ & 129 & $p<0.001$ \\
\hline$E / I$ or $f$ & $0.7(0.3)$ & $0.6(0.2)$ & $0.2(0.2)$ & 218 & $p<0.001$ \\
\hline $\mathrm{TC}(\mathrm{ppm})$ & $8.7(4.0)$ & $19.9(6.6)$ & $30.8(9.4)$ & 666 & $p<0.001$ \\
\hline DOC (ppm) & $6.7(3.5)$ & $3.9(1.2)$ & $6.7(5.2)$ & 649 & $p<0.001$ \\
\hline DIC (ppm) & $2.0(1.3)$ & $15.9(7.2)$ & $24.1(11.5)$ & 644 & $p<0.001$ \\
\hline $\mathrm{TN}(\mathrm{ppm})$ & $0.6(0.2)$ & $0.4(0.1)$ & $0.5(0.3)$ & 2 & $p<0.001$ \\
\hline Atomic $\mathrm{C} / \mathrm{N}$ & $14.1(3.5)$ & $11.1(1.4)$ & $14.0(4.3)$ & 666 & $p<0.001$ \\
\hline Elevation $(\mathrm{m})$ & $287.0(4.6)$ & $286.7(7.6)$ & $275.1(3.0)$ & 1275 & $p<0.001$ \\
\hline Maximum depth (m) & $12.0(6.6)$ & $12.4(5.7)$ & $13.5(6.8)$ & 1701 & $p<0.001$ \\
\hline Maximum lake perimeter slope (\%) & $10.2(7.4)$ & $11.3(6.7)$ & $19.9(6.7)$ & 1272 & $p<0.001$ \\
\hline
\end{tabular}




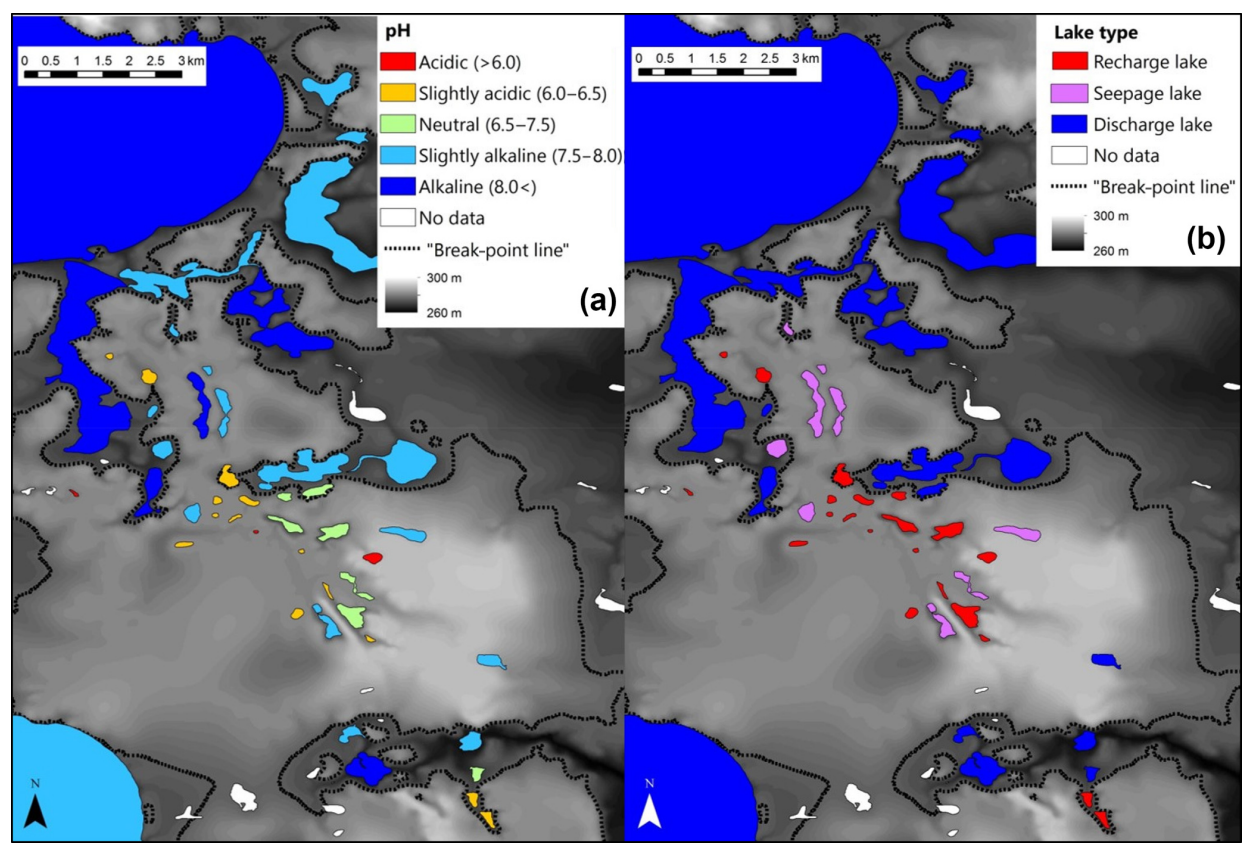

Figure A1. Spatial depiction between elevation and lake-water pH (a) and lake type (b). The elevation of the breakpoint line (284 m) is shown as a dashed line.
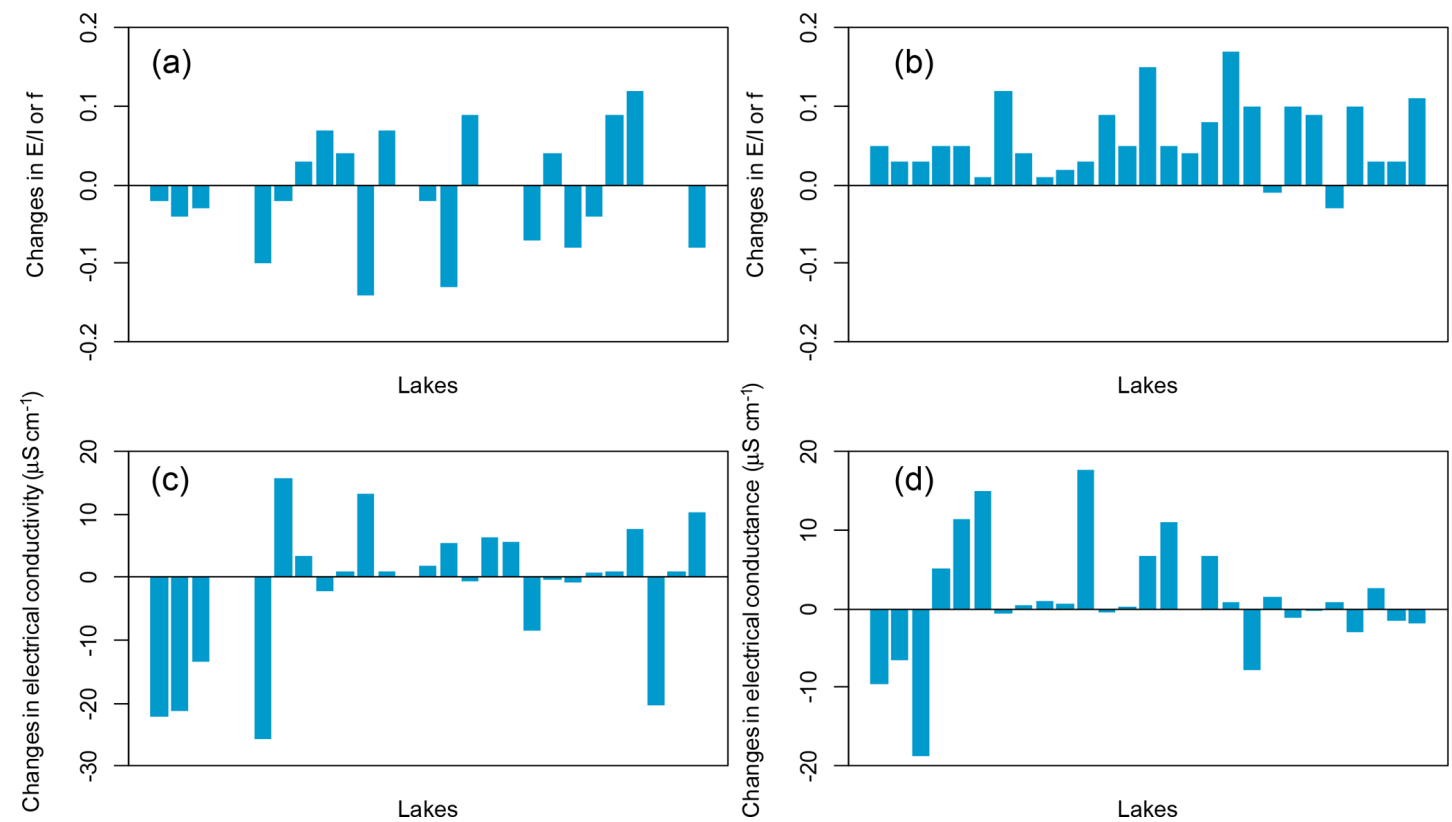

Figure A2. Changes in $E / I$ or $f$ between June 2013 and June 2014 ( $E / I$ or $f 2014$ to $E / I$ or $f$ 2013) (a), changes in $E / I$ or $f$ between August 2014 and June 2014 ( $E / I$ or $f$ August to $E / I$ or $f$ June) (b), changes in specific conductance between June 2013 and June 2014 (EC 2014-EC 2013) (c), and changes in electrical conductance between August 2014 and June 2014 (EC August-EC June) (d). Lakes are organized along an elevation gradient (lower to higher elevation). 
Data availability. The data can be made available by contacting the corresponding author.

Author contributions. MPB collected data in the field and processed samples in the lab, conducted data analysis and interpretation (with input from all authors), and generated figures and tables. SFL provided guidance and funding and reviewed and edited the paper in his function as supervisor, as did BFC. The paper was written by MPB, with input from all the authors.

Competing interests. The authors declare that they have no conflict of interest.

Special issue statement. This article is part of the special issue "Assessing impacts and adaptation to global change in water resource systems depending on natural storage from groundwater and/or snowpacks". It is not associated with a conference.

Acknowledgements. This work was supported by the Natural Sciences and Engineering Research Council of Canada (NSERC) to Scott Lamoureux (Discovery Grant 227165) and by the Graduate Dean's Doctoral Field Travel Grant from Queen's University to Maxime Boreux. The authors want to thank Graham Mushet, Gladys Kong, Cécilia Barouillet and Dan Lamhonwah for their field assistance; Steve Koziar, Allison Rutter, Liz Kjikjerkovska and Dan Lamhonwah for their assistance in the lab; and Melissa Lafrenière and Ontario Parks for their logistical support. Many thanks to local property owners, in particular to Franca Adamo-Wheeler, Jessica Adamo and their family; to Rob and Mary Ann Stewart; and to Ron and Tarja Bouchard, who allowed access to their property for lake sampling, shared precious field information and kindly offered logistic support. The authors thank the editor, along with Kevin Turner and the three other anonymous reviewers for their valuable remarks, allowing the improvement of the paper.

Financial support. This research has been supported by the Natural 30 Sciences and Engineering Research Council of Canada to SL (grant no. 227165) and by the Graduate Dean's Doctoral Field Travel Grant from Queen's University to MB.

Review statement. This paper was edited by Nandita Basu and reviewed by Kevin Turner and three anonymous referees.

\section{References}

Ala-aho, P., Rossi, P. M., and Kløve, B.: Interaction of esker groundwater with headwater lakes and streams, J. Hydrol., 500, 144 156, https://doi.org/10.1016/j.jhydrol.2013.07.014, 2013.

Ala-aho, P., Rossi, P. M., Isokangas, E., and Kløve, B.: Fully integrated surface-subsurface flow modelling of groundwater-lake interaction in an esker aquifer: Model verification with stable isotopes and airborne thermal imaging, J. Hydrol., 522, 391-406, https://doi.org/10.1016/j.jhydrol.2014.12.054, 2015a.

Ala-aho, P., Rossi, P. M., and Kløve, B.: Estimation of temporal and spatial variations in groundwater recharge in unconfined sand aquifers using Scots pine inventories, Hydrol. Earth Syst. Sci., 19, 1961-1976, https://doi.org/10.5194/hess-19-1961-2015, $2015 b$.

Anderson, M. P. and Munter, J. A.: Seasonal reversals of groundwater flow around lakes and the relevance to stagnation points and lake budgets, Water Resour. Res., 17, 1139-1150, https://doi.org/10.1029/WR017i004p01139, 1981.

Arnoux, M., Barbecot, F., Gibert-Brunet, E., Gibson, J., Rosa, E., Noret, A. and Monvoisin, G.: Geochemical and isotopic mass balances of kettle lakes in southern Quebec (Canada) as tools to document variations in groundwater quantity and quality, Environ. Earth Sci., 76, 106, https://doi.org/10.1007/s12665-0176410-6, 2017a.

Arnoux, M., Gibert-Brunet, E., Barbecot, F., Guillon, S., Gibson, J., and Noret, A.: Interactions between groundwater and seasonally ice-covered lakes: using water stable isotopes and radon-222 multi-layer mass balance models, Hydrol. Process., 31, 25662581, https://doi.org/10.1002/hyp.11206, 2017 b.

Bennett, D. M., Fritz, S. C., Holz, J. C., and Zlotnik, V. A.: Evaluating climatic and non-climatic influences on ion chemistry in natural and man-made lakes of Nebraska, USA, Hydrobiologia, 591, 103-115, https://doi.org/10.1007/s10750-007-0798-z, 2007.

Bertrand, G., Siergieiev, D., Ala-Aho, P., and Rossi, P. M.: Environmental tracers and indicators bringing together groundwater, surface water and groundwater dependent ecosystems: importance of scale in choosing relevant tools, Environ. Earth Sci., 7, 813827, https://doi.org/10.1007/s12665-013-3005-8, 2014.

Birks, S. J., Edwards, T. W. D., Gibson, J. J., Michel, F. A., Drimmie, R. J., MacTavish, D., Remenda, V. H., and Wassenaar, L. I.: Canadian Network for Isotopes in Precipitation, University of Waterloo, Ontario, Canada, available at: http: //science.uwaterloo.ca/ twdedwar/cnip/cniphome.html, last access: 23 May 2015.

Born, S. M., Smith, S. A., and Stephenson, D. A.: Hydrogeology of glacial-terrain lakes, with management and planning applications, J. Hydrol., 43, 7-43, https://doi.org/10.1016/00221694(79)90163-X, 1979.

Bouchard, F., Turner, K. W., MacDonald, L. A., Deakin, C., White, H., Farquharson, N., Medeiros, A. S., Wolfe, B. B., Hall, R. I., Pienitz, R., and Edwards, T. W. D.: Vulnerability of shallow subarctic lakes to evaporate and desiccate when snowmelt runoff is low, Geophys. Res. Lett., 40, 6112-6117, https://doi.org/10.1139/as-2016-0019, 2013.

Cloutier, V., Veillette, J., Roy, M., Bois, D., Gagnon, F., and de Corta, H.: Atlas sur les eaux souterraines de la MRC d'Abitibi, Université du Québec en Abitibi-Témiscamingue, Québec, Canada, 24 pp., 36 maps, 2007. 
Cloutier, V., Blanchette, D., Dallaire, P.-L., Nadeau, S., Rosa, E., and Roy, M.: Projet d'acquisition de connaissances sur les eaux souterraines de l'Abitibi-Témiscamingue (partie 1) [AbitibiTémiscamingue groundwater knowledge acquisition project, Part 1], Rapport final [Final Report], Amos: Groupe de recherche sur l'eau souterraine. Institut de recherche en mines et en environnement. Université du Québec en Abitibi-Témiscamingue, Québec, Canada, 151 pp., 2013.

Cochrane, L. B.: Technical report on the Aquarius Project, Timmins, Ontario, Canada, St. Andrew Goldfields LTD, 129 pp., 2006.

Cohen, M. J., Creed, I. F., Alexander, L., Basu, N. B., Calhoun, A. J. K., Craft, C., D’Amico, E., DeKeyser, E., Fowler, L., Golden, H. E., Jawitz, J. W., Kalla, P., Kirkman, L. K., Lane, C. R., Lang, M., Leibowitz, S. G., Lewis, D. B., Marton, J., McLaughlin, D. L., Mushet, D. M., Raanan-Kiperwas, H., Rains, M. C., Smith, L., and Walls, S. C.: Do geographically isolated wetlands influence landscape functions?, P. Natl. Acad. Sci. USA, 113, 1978-1986, https://doi.org/10.1073/pnas.1512650113, 2016.

Craig, H. and Gordon, L. I.: Deuterium and Oxygen-18 Variations in the Ocean and the Marine Atmosphere, in: Stable Isotopes in Oceanographic Studies and Paleotemperatures, edited by: Tongiorgi, E., Laboratorio di geologia nucleare, Pisa, Italy, 9-130, 1965.

Cummings, D. I., Gorrell, G., Guilbault, J.-P., Hunter, J. A., Logan, C., Ponomarenko, D., Pugin, A. J.-M., Pullan, S. E., Russell, H. A. J., and Sharpe, D. R.: Sequence stratigraphy of a glaciated basin fill, with a focus on esker sedimentation, Geol. Soc. Am. Bull., 123, 1478-1496, https://doi.org/10.1130/B30273.1, 2011.

Darling, W. G., Bath, A. H., Gibson, J. J., and Rozanski, K.: Isotopes in Water, in: Isotopes in Palaeoenvironmental Research, edited by: Leng, M. J., Springer, Dordrecht, the Netherlands, 166, 2005.

Dyke, A. S.: An outline of North American deglaciation with emphasis on central and northern Canada, in: Quaternary glaciations - extent and chronology, part II: North America, Developments in Quaternary Science 2b, edited by: Ehlers, J. and Gibard, P. L., Elsevier, Amsterdam, the Netherlands, 373-424, 2004.

Environment Canada: Historical climate data for Timmins, Ontario, available at: http://climate.weather.gc.ca/historical_data/search_ historic_data_e.html, last access: 6 June 2015.

Fleckenstein, J. H., Krause, S., Hannah, D. M., and Boano, F.: Groundwater-surface water interactions: new methods and models to improve understanding of processes and dynamics, Adv. Water Resour., 33, 1291-1295, https://doi.org/10.1016/j.advwatres.2010.09.011, 2010.

Fritz, S. C., Ito, E., Yu, Z., Laird, K., and Engstrom, D. R.: Hydrologic variation in the Northern Great Plains during the last two millennia, Quaternary Res., 53, 175-184, https://doi.org/10.1006/qres.1999.2115, 2000.

Gazis, C. and Feng, X.: A stable isotope study of soil water: evidence for mixing and preferential flow paths, Geoderma, 119, 97-111, https://doi.org/10.1016/S0016-7061(03)00243-X, 2004.

Gibson, J. J.: A new conceptual model for predicting isotope enrichment of lakes in seasonal climates, PAGES News, 10, 10-11, https://doi.org/10.22498/pages.10.2.10, 2002.

Gibson, J. J. and Edwards, T. W. D.: Regional surface water balance and evaporation-transpiration partitioning from a stable isotope survey of lakes in northern Canada, Global Biogeochem. Cy., 16, 1-14, https://doi.org/10.1029/2001GB001839, 2002.

Gibson, J. J., Edwards, T. W. D., Bursey, G. G., and Prowse, T. D.: Estimating evaporation using stable isotopes: quantitative results and sensitivity analysis for two catchments in northern Canada, Nord. Hydrol., 24, 79-94, https://doi.org/10.2166/nh.1993.0015, 1993.

Gibson, J. J., Birks, S. J., and Edwards, T. W. D.: Global prediction of $\delta_{\mathrm{A}}$ and $\delta^{2} \mathrm{H}-\delta^{18} \mathrm{O}$ evaporation slopes for lakes and soil water accounting for seasonality, Global Biogeochem. Cy., 22, GB2031, https://doi.org/10.1029/2007GB002997, 2008.

Gonfiantini, R.: Environmental isotopes in lake studies, in: Handbook of Environmental Isotope Geochemistry, Vol. 2, The Terrestrial Environment, edited by: Fritz, B. P. and Fontes, J. C., Elsevier, Amsterdam, the Netherlands, 113-168, 1986.

Gorham, E., Dean, W. E., and Sanger, J. E.: The chemical composition of lakes in the north-central United States, Limnol. Oceanogr., 28, 287-301, https://doi.org/10.4319/lo.1983.28.2.0287, 1983.

Granger, R. J. and Hedstrom, N.: Modelling hourly rates of evaporation from small lakes, Hydrol. Earth Syst. Sci., 15, 267-277, https://doi.org/10.5194/hess-15-267-2011, 2011.

Gurrieri, J. T. and Furniss, G.: Estimation of groundwater exchange in alpine lakes using non-steady mass-balance methods, J. Hydrol., 297, 187-208, https://doi.org/10.1016/j.jhydrol.2004.04.021, 2004.

Horita, J. and Wesolowski, D.: Liquid-vapour fractionation of oxygen and hydrogen isotopes of water from the freezing to the critical temperature, Geochim. Cosmochim. Ac., 58, 3425-3437, https://doi.org/10.1016/0016-7037(94)90096-5, 1994.

Isokangas, E., Rozanski, K., Rossi, P. M., Ronkanen, A.-K., and Kløve, B.: Quantifying groundwater dependence of a sub-polar lake cluster in Finland using an isotope mass balance approach, Hydrol. Earth Syst. Sci., 19, 1247-1262, https://doi.org/10.5194/hess-19-1247-2015, 2015.

Katz, B. G., Coplen, T. B., Bullen, T. D., and Davis, J. H.: Use of chemical and isotopic tracers to characterize the interactions between ground water and surface water in mantled karst, Ground Water, 35, 1014-1028, https://doi.org/10.1111/j.17456584.1997.tb00174.x, 1997.

Kendall, C. and Caldwell, E. A.: Fundamentals of Isotope Geochemistry, in: Isotope Tracers in Catchment Hydrology, edited by: Kendall, C. and McDonnell J. J., Elsevier Science B.V., Amsterdam, the Netherlands, 51-86, 1998.

Kenoyer, G. J. and Anderson, M. P.: Groundwater's dynamic role in regulating acidity and chemistry in a precipitation-dominated lake, J. Hydrol., 109, 287-306, https://doi.org/10.1016/00221694(89)90020-6, 1989.

Kløve, B., Ala-aho, P., Bertrand, G., Boukalova, Z., Ertürk, A., Goldscheider, N., Ilmonen, J., Karakaya, N., Kupfersberger, H., Kværner, J., Lundberg, A., Mileusnic, M., Moszczynska, A., Muotka, T., Preda, E., Rossi, P., Siergieiev, D., Šimek, J., Wachniew, P., and Widerlund, A.: Groundwater dependent ecosystems: Part I - Hydroecology, threats and status of ecosystems, Environ. Sci. Policy, 14, 770-781, https://doi.org/10.1016/j.envsci.2011.04.002, 2011.

Knoll, L. B., Hagenbuch, E. J., Stevens, M. H., Vanni, M. J., Renwick, W. H., Denlinger, J. C., Hale, R. S., and González, M. J.: Predicting eutrophication status in reservoirs at large spatial 
scales using landscape and morphometric variables, Inland Waters, 5, 203-214, https://doi.org/10.5268/IW-5.3.812, 2015.

Kratz, T., Webster, K., Bowser, C., Magnuson, J., and Benson, B.: The influence of landscape position on lakes in northern Wisconsin, Freshwater Biol., 37, 209-217, https://doi.org/10.1046/j.1365-2427.1997.00149.x, 1997.

LaBaugh, J. W., Winter, T. C., Rosenberry, D. O., Schuster, P. F., Reddy, M. M., and Aitken, G. R.: Hydrological and chemical estimates of the water balance of a closed-basin lake in north central Minnesota, Water Resour. Res., 33, 2799-2812, https://doi.org/10.1029/97WR02427, 1997.

Laird, K. R., Haig, H. A., Ma, S., Kingsbury, M. V., Brown, T. A., Lewis, C. F. M., Oglesby, R. J., and Cumming, B. F.: Expanded spatial extent of the Medieval Climate Anomaly revealed in lake-sediment records across the boreal region in northwest Ontario, Glob. Change Biol., 18, 2869-2881, https://doi.org/10.1111/j.1365-2486.2012.02740.x, 2012.

Lewandowski, J., Meinikmann, K., Nützmann, G. and Rosenberry, D. O.: Groundwater - the disregarded component in lake water and nutrient budgets. Part 2: effects of groundwater on nutrients, Hydrol. Process., 29, 2922-2955, https://doi.org/10.1002/hyp.10384, 2015.

Louiseize, N. L., Lafrenière, M. J., and Hastings, M. J.: Stable isotopic evidence of enhanced export of microbially derived $\mathrm{NO}_{3}$ following active layer slope disturbance in the Canadian High Arctic, Biogeochemistry, 121, 565-580, https://doi.org/10.1007/s10533-014-0023-x, 2014.

Martin, S. L. and Soranno, P. A.: Lake landscape position: relationships to hydrologic connectivity and landscape features, Limnol. Oceanogr., 51, 801-814, https://doi.org/10.4319/lo.2006.51.2.0801, 2006.

Martin, S. L., Soranno, P. A., Bremigan, M. T., and Cheruvelil, K. S.: Comparing hydrogeomorphic approaches to lake classification, Environ. Manage., 48, 957-974, https://doi.org/10.1007/s00267-011-9740-2, 2011.

Mulholland, P. J.: Large scale patterns of dissolved organic carbon concentration, flux and sources, in: Aquatic Ecosystems: Interactivity of Dissolved Organic Matter, edited by: Findlay, S. E. G. and Sinsabaugh, R. L., Elsevier Science, San Diego, California, USA, 139-160, 2003.

Natural Resources Canada: GeoGratis (version 2.1): available at: http://geogratis.cgdi.gc.ca/, 30 August 2019.

Newton, R. M. and Driscoll, C. T.: Classification of ALSC lakes, in: Adriondack Lakes Survey: An Interpretive Analysis of Fish Communities and Water Chemistry, 1984-87, edited by: Baker, J. P., Gherini, S. A., Munson, R. K., Christensen, S. W., Driscoll, C. T., Gallagher, J., Newton, R. M., Reckhow, K. H., and Schofield, C. L., Adriondack Lakes Survey Corporation, Ray Brook, New York, USA, 270-291, 1990.

Okkonen, J. and Kløve, B.: A sequential modelling approach to assess groundwater-surface water resources in a snow dominated region of Finland, J. Hydrol., 411, 91-107, https://doi.org/10.1016/j.jhydrol.2011.09.038, 2011.

Ontario Ministry of Natural Resources and Forestry: Fish ON-Line, available at: https://www.gisapplication.lrc.gov. on.ca/FishONLine/Index.html?site=FishONLine\&viewer= FishONLine\&locale=en-US, last access: 23 October 2011.

Ontario Ministry of Northern Development and Mines: Soils of Timmins-Noranda-Rouyn area: soil survey report No 46, avail- able at: http://www.geologyontario.mndm.gov.on.ca/, last access: 19 October 2013.

Quinlan, R., Paterson, A. M., Hall, R. I., Dillon, P. J., Wilkinson, A. N., Cumming, B. F., Douglas, M. S. V., and Smol, J. P.: A landscape approach to examining spatial patterns of limnological variables and long-term environmental change in a southern Canadian lake district, Freshwater Biol., 48, 1676-1697, https://doi.org/10.1046/j.1365-2427.2003.01105.x, 2003.

Rautio, A. and Korkka-Niemi, K.: Characterization of groundwater-lake water interactions at Pyhäjärvi, a lake in SW Finland, Boreal Environ. Res., 16, 363-380, https://doi.org/10.1108/14777831211204958, 2011.

Rey, N., Rosa, E., Cloutier, V., and Lefebvre, R.: Using water stable isotopes for tracing surface and groundwater flow systems in the Barlow-Ojibway Clay Belt, Quebec, Canada, Can. Water Resour. J., 43, 173-194, https://doi.org/10.1080/07011784.2017.1403960, 2018.

Richard, J. A. and McClenaghan, M. B.: Quaternary geology of the Porquis Junction area, Ontario Geological Survey, Map 2659, scale 1:50000, 2000.

Rosenberry, D. O., Lewandowski, J., Meinikmann, K., and Nützmann, G.: Groundwater - the disregarded component in lake water and nutrient budgets. Part 1: effects of groundwater on hydrology, Hydrol. Process., 29, 2895-2921, https://doi.org/10.1002/hyp.10403, 2015.

Rossi, P. M., Ala-aho, P., Ronkanen, A., and Kløve, B.: Groundwater-surface water interaction between an esker aquifer and a drained fen, J. Hydrol., 432-433, 52-60, https://doi.org/10.1016/j.jhydrol.2012.02.026, 2012.

Roy, M., Dell'Oste, F., Veillette, J. J., de Vernal, A., Hélie, J.-F., and Parent, M.: Insights on the events surrounding the final drainage of Lake Ojibway based on James Bay stratigraphic sequences, Quaternary Sci. Rev., 30, 682-692, https://doi.org/10.1016/j.quascirev.2010.12.008, 2011.

Schuster, P. F., Reddy, M. M., LaBaugh, J. W., Parkhurst, R. S., Rosenberry, D. O., Winter, T. C., Antweiler, R. C., and Dean, W. E.: Characterization of lake water and ground water movement in the littoral zone of Williams Lake, a closed-basin lake in north central Minnesota, Hydrol. Process., 17, 823-838, https://doi.org/10.1002/hyp.1211, 2003.

Sebestyen, S. D. and Schneider, R. L.: Dynamic temporal patterns of nearshore seepage flux in a headwater Adirondack lake, J. Hydrol., 247, 137-150, https://doi.org/10.1016/S00221694(01)00377-8, 2001.

Skrzypek, G., Mydłowski, A., Dogramaci, S., Hedley, P., Gibson, J., and Grierson, P.: Estimation of evaporative loss based on the stable isotope composition of water using "Hydrocalculator", J. Hydrol., 523, 781-789, https://doi.org/10.1016/j.jhydrol.2015.02.010, 2015.

Smerdon, B. D., Devito, K. J., and Mendoza, C. A.: Interaction of groundwater and shallow lakes on outwash sediments in the subhumid Boreal Plains region, J. Hydrol., 314, 246-262, https://doi.org/10.1016/j.jhydrol.2005.04.001, 2005.

Smerdon, B. D., Devito, K. J., and Mendoza, C. A.: Simulations of fully coupled lake-groundwater exchange in a subhumid climate with an integrated hydrologic model, Water Resour. Res., 43, W01416, https://doi.org/10.1029/2006WR005137, 2007. 
Stauffer, R. E. and Wittchen, B. D.: Hydrogeochemistry of Maine seepage lakes and related groundwaters, J. Hydrol., 138, 559581, https://doi.org/10.1016/0022-1694(92)90137-K, 1992.

Thorslund, J., Cohen, M. J., Jawitz, J. W., Destouni, G., Creed, I. F., Rains, M. C., Badiou, P., and Jarsjö, J.: Solute Evidence for Hydrological Connectivity of Geographically Isolated Wetlands, Land Degrad. Dev., 29, 3954-3962, https://doi.org/10.1002/ldr.3145, 2018.

Tóth, J.: A theoretical analysis of groundwater flow in small drainage basins, J. Geophys. Res., 68, 4795-4812, https://doi.org/10.1029/JZ068i016p04795, 1963.

Tondu, J. M., Turner, K. W., Wolfe, B. B., Hall, R. I., Edwards, T. W. D., and McDonald, I.: Using water isotope tracers to develop the hydrological component of a long-term aquatic ecosystem monitoring program for a northern lake-rich landscape, Arct. Antarct. Alp. Res., 45, 594-614, https://doi.org/10.1657/19384246-45.4.594, 2013.

Turner, J. V. and Townley, L. R.: Determination of groundwater flow-through regimes of shallow lakes and wetlands from numerical analysis of stable isotope and chloride tracer distribution patterns, J. Hydrol., 320, 451-483, https://doi.org/10.1016/j.jhydrol.2005.07.050, 2006.

Turner, K. W., Wolfe, B. B., and Edwards, T. W. D.: Characterizing the role of hydrological processes on lake water balances in the Old Crow Flats, Yukon Territory, Canada, using water isotope tracers, J. Hydrol., 386, 103-117, https://doi.org/10.1016/j.jhydrol.2010.03.012, 2010.

Turner, K. W., Edwards, T. W. D., and Wolfe, B. B.: Characterizing runoff generation processes in a lake-rich thermokarst landscape (Old Crow Flats, Yukon, Canada) using $\delta^{18} \mathrm{O}, \delta^{2} \mathrm{H}$ and d-excess measurements, Permafrost Periglac., 25, 53-59, https://doi.org/10.1002/ppp.1802, 2014a.

Turner, K. W., Wolfe, B. B., Edwards, T. W. D., Lantz, T. C., Hall, R. I., and Larocque, G.: Controls on water balance of shallow thermokarst lakes and their relations with catchment characteristics: a multi-year, landscape-scale assessment based on water isotope tracers and remote sensing in Old Crow Flats, Yukon (Canada), Glob. Change Biol., 20, 1585-1603, https://doi.org/10.1111/gcb.12465, 2014b.
Webster, K. E., Kratz, T. K., Bowser, C. J., Magnuson, J. J., and Rose, W. J.: The influence of landscape position on lake chemical responses to drought in northern Wisconsin, Limnol. Oceanogr., 41, 977-984, https://doi.org/10.4319/lo.1996.41.5.0977, 1996.

Webster, K. E., Soranno, P. A., Baines, S. B., Kratz, T. K., Bowser, C. J., Dillon, P. J., Campbell, P., Fee, E. J., and Hecky, R. E.: Structuring features of lake districts: landscape controls on lake chemical responses to drought, Freshwater Biol., 43, 499-515, https://doi.org/10.1046/j.1365-2427.2000.00571.x, 2000.

Winter, T. C.: Numerical simulation analysis of the interaction of lakes and groundwater, United States Geological Survey Professional Papers, 1001, https://doi.org/10.3133/pp1001, 1976.

Winter, T. C.: Classification of the hydrologic setting of lakes in the north central United States, Water Resour. Res., 13, 753-767, https://doi.org/10.1029/WR013i004p00753, 1977.

Winter, T. C.: Relation of streams, lakes, and wetlands to groundwater flow systems, Hydrogeol. J., 7, 28-45, https://doi.org/10.1007/s100400050178, 1999.

Winter, T. C., Harvey, J. W., Franke, O. L., and Alley, W. W.: Ground water and surface water: a single resource, in: U.S. Geological Survey Circular 1139, U.S. Geological Survey, Denver, Colorado, USA, 1998.

Winter, T. C., Rosenberry, D. O., and LaBaugh, J. W.: Where does the ground water in small watersheds come from?, Ground Water, 41, 989-1000, https://doi.org/10.1111/j.17456584.2003.tb02440.x, 2003.

Wolfe, B. B., Karst-Riddoch, T. L., Hall, R. I., Edwards, T. W. D., English, M. C., Palmini, R., McGowan, S., and Vardy, S. R.: Classification of hydrologic regimes of northern floodplain basins (Peace-Athabasca Delta, Canada) from analysis of stable isotopes $\left(\delta^{18} \mathrm{O}, \delta^{2} \mathrm{H}\right)$ and water chemistry, Hydrol. Process., 21, 151-168, https://doi.org/10.1002/hyp.6229, 2007.

Yi, Y., Brock, B. E., Falcone, M. D., Wolfe, B. B., and Edwards, T. W. D.: A coupled isotope tracer method to characterize input water to lakes, J. Hydrol., 350, 1-13, https://doi.org/10.1016/j.jhydrol.2007.11.008, 2008. 